\title{
EFFECT OF DIFFERENT IRRIGATION INTERVALS AND TREATMENTS ON YIELD QUANTITY AND QUALITY OF POTATO (SOLANUM TUBEROSUM L.) UNDER FIELD CONDITIONS IN SULAIMANI, IRAQI KURDISTAN REGION
}

\author{
BARZNJY, L. G. K. ${ }^{1}-$ AlLAWI, M. M. ${ }^{2}-$ MAHOOD, N. A. ${ }^{3}$ \\ ${ }^{1}$ Horticulture Department, College of Agricultural Enginerring Sciences, University of \\ Sulaimani, Sulaimani, Kurdistan Region, Iraq \\ ${ }^{2}$ Horticulture Department, College of Agricultural Engineering Sciences, University of \\ Baghdad, Iraq \\ ${ }^{3}$ Protected Agricultural Department, Bakrajo Technical Agriculture Institute, Sulaimani, Iraq \\ *Corresponding author \\ e-mail:luqman.karim@univsul.edu.iq; phone:+964-770-143-4161
}

(Received $13^{\text {th }}$ Jun 2019; accepted $16^{\text {th }}$ Oct 2019)

\begin{abstract}
This study was carried out in two growing spring seasons 2017 and 2018 at Kanipanka

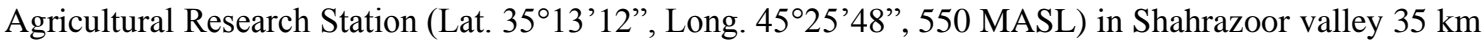
east of Sulaimani. The aim was to investigate the effect of two irrigation intervals (5 and 10 days) and thirteen biotic and abiotic treatments on yield quantity and quality of potato under field condition. The results showed that the 5 days irrigation intervals gave the maximum values of total yield, Total Soluble Solute percentage, while 10 days of irrigation intervals obtained the highest values of tuber hardness and all of the amino acids in the tuber seasons 2017 and 2018, while the maximum values of total yield were acquired through mycorrhizal inoculation. Total Soluble Solute and tuber hardness were achieved by potassium chloride treatment. Whereas the maximum values of all amino acid in the tuber were given by the mycorrhizal inoculation treatment with $\left(6 \mathrm{~g} \mathrm{~L}^{-1}\right)$ of Glycyrrhiza glabra extract in the first season 2017. Concerning the second season 2018, the maximum total yield gave by treatment of potassium chloride and $\left(6 \mathrm{~g} \mathrm{~L}^{-1}\right)$ of Glycyrrhiza glabra extract, while the potassium chloride treatment gave the maximum values of Total Soluble Solute in the tuber.
\end{abstract}

Keywords: watering period, T.S.S and starch percentage, proline, glycine, lucien, lysine

\section{Introduction}

Potato (Solanum tuberosum L.), which belonging to the Solanaceae family, is the fourth most important agronomical feed crop worldwide after winter wheat, maize, and rice. The total world production of potatoes was 388 million $t$ in 2017, (FAOSTA, 2019). The potato production in Iraq was more than $190,000 \mathrm{t}$ with a total cultivated area of 7950 ha on average $23.996 \mathrm{t} \mathrm{h}^{-1}$ (Central Statistical Organization, 2016). Regarding the Kurdistan Region, the potato production was estimated to be over $150,000 \mathrm{t}$ in 2016 data to the Ministry of Agriculture and Water Resources in the Iraqi Kurdistan region.

Irrigation aimed for supplying water totally or partially for crop requirements, decreasing soil and plant temperature, leach excess salts, increase storage of groundwater, facilitate continuous cropping, and to enhance fertilizer application. Some other benefits of irrigation include the direct cut on water stress, increasing the investment in inputs such as fertilizers and improving cultivars affected by uncertain crop production under rained conditions (Zotarelli et al., 2009). 
Muthoni and Kabira (2016) reported that water is the most important limiting factor for potato production and it is possible to increase production levels by well-scheduled irrigation programs throughout the growing season in Tigoni, Kenya. Water stress limits crop productivity by affecting photosynthetic processes at the canopy, or by feedback, inhibition if the transport of photosynthesis to sink organs is limited (Murchie et al., 2009). Moisture stress first causes stomatal closure thus reducing $\mathrm{CO}_{2}$ uptake for photosynthesis; this leads to reduced plant growth and yield (Mafakheri et al., 2010). Sugar concentration within the leaf tissue increases to increase the osmotic potential of the plant, these clues to response inhibition of photosynthesis (Basu et al., 1999). Finkel and Holbrook (2000) found that the water stresses affected to increased accumulation of reactive oxygen species (ROS) in plants such as $\left(\mathrm{O}_{2}^{-}, \mathrm{H}_{2} \mathrm{O}_{2}\right)$. Overproduction of ROS can disrupt normal plant metabolism through impaired enzyme activity due to oxidative damage, protein degradation.

The natural plant extracted can be achieved easily, safely and cheaply. Furthermore, it is considered as highly eco-friendly compounds. Sarby et al. (2009) reported that licorice root extract contains some compounds, which have similar effect to the growth promoters. Also have a wide range of minerals ( $\mathrm{P}, \mathrm{K} \mathrm{Zn}, \mathrm{Mg}, \mathrm{Fe}$, and $\mathrm{Ca}$ ), amino acids (alanine, lysine, arginine), vitamins $\left(\mathrm{B}_{1}, \mathrm{~B}_{2}, \mathrm{~B}_{6}\right)$, with carbohydrate and nitrogen addition, It also contains mevalonic acid that can be used in gibberellins synthesis. Matar et al. (2012) found that the spray $\left(5 \mathrm{~g} \mathrm{~L}^{-1}\right)$ of licorice extract significantly increased protein percentage in tubers with the maximum values of the total and marketable yield of the potato plant. 5\% foliar application with licorice extracts resulted in significant increases total tube, and marketable yields and in addition to decreases in physiological disorders and mechanical injury of tomato plants (Fan et al., 2016). ELSagan (2015) reported that the mechanism of action of licorice extract in plants is similar to the gibberellic acid action in stimulating of vegetative growth of plants. Moreover, the licorice extract is available, low cost and effective easy to apply. In addition licorice, foliar applications increase the percentages of N, P, and K in plant's leaves, chlorophyll content in the leaves of cucumber (Khalel and Hado, 2011).

The role of potassium in molecular mechanisms and physiological stress resistance, furthermore, ROS damage would be justifying by $\mathrm{K}$ under water stress conditions that resulting in the cell death (Wang et al., 2013). Potassium foliar application is another factor that has been used for improved nutrient management and increasing potato growth and yield (Fageria et al., 2016). Asmaa and Magda (2010) concluded that the total yield of potato tubers significantly with the increases of potassium level in tow season growth. In addition, they concluded that the potassium application significantly affected tubers nutritive values. Maximum tuber yield $36.65 \mathrm{t} \mathrm{ha}^{-1}$ was obtained from $600 \mathrm{~kg} \mathrm{~K}_{2} \mathrm{SO}_{4} \mathrm{ha}^{-1}$ for trickle irrigation and $35.23 \mathrm{t} \mathrm{ha}^{-1}$ for furrow irrigation. Interaction between irrigation and potassium fertilization were significantly affected in relation to leaf area, the relative water content in leaves, water potential, stomatal resistance and number of the tiny and marketable tuber of potato (Khosravifar et al., 2008). Zelelew et al. (2016) reported that potato needs different plant nutrients for both growth and developments lacking such nutrients caused the reduction in both qualities and quantities of tubers. AL-Alousi (2013) Studied the effect of potassium fertilizer with three levels $(0,200$ and $400 \mathrm{~kg}$ potassium ha $\left.{ }^{-1}\right)$ in form of $\mathrm{K}_{2} \mathrm{SO}_{4}$, also spray with two levels of potassium sulfate $(0$ and $5000 \mathrm{mg}$ potassium $\left.\mathrm{L}^{-1}\right)$ and spray with organic extract $\left(0\right.$ and $\left.10 \mathrm{ml} \mathrm{L}^{-1}\right)$. The results show the addition and spraying of potassium gave the highest values of vegetative day weight, total tuber yields, number of tuber plant ${ }^{-1}$, tuber weight and percentage of starch 
in tuber with $6243.33 \mathrm{~kg} \mathrm{~h}^{-1}, 36.07 \mathrm{t} \mathrm{h}^{-1}, 6.45$ tuber plant ${ }^{-1}, 140.33 \mathrm{~g} \mathrm{tuber}^{-1}$ and $12.41 \%$ for treatments K400, F5000 and M10 respectively.

Tuber dry matter is a varietal character; however, growing location, season, climatic conditions and cultural practices greatly affect the accumulation of dry matter in tubers, a dry matter content of more than $20 \%$ is considered ideal for making chips (Saran and Chhabra, 2014). As a food, potato ranks second to soybean in protein amount produced per hectare, and second to sugarcane in carbohydrate production (Alavijeh and Yaghmaei, 2016). Chakraborty et al. (2010) showed that potato tuber proteins have been found to be of high nutritional value.

The mycorrhiza's function is enhancing the processes of nutrient absorption from the soil and increase the plant resistance against drought and diseases. Microorganisms are an essential component of the agricultural system. Mycorrhizae are a global soil microbe, can subordinate with the roots of most native crop species (Duc, 2017). Several benefits were observed when arbuscular mycorrhizal (AM) fungi is colonized crops including; increased growth and yield, enhanced plant resistance to environmental adversities, increase the plant resistance to abiotic stress (Birhane et al., 2012). ROS production, and thus antioxidant enzyme activity, is enhanced when plants are exposed to various abiotic stresses, such as drought (Caverzan et al., 2012). Osmosis is a mechanism for maintaining water relations under osmotic pressure. It involves the accumulation of a group of active/osmotic molecules/ions including dissolved sugars, sugar alcohol, proline, glycine betaine, organic acids, calcium, potassium, chloride ions and others under water shortage and due to the dissolved accumulation of the cell, which attracts water to the cell and helps maintain the turgor. Potatoes respond to dehydration and salts accumulated through the accumulation of proline which acts as an endoscopy device (osmoprotector), osmoregulator and ROS scavenger (Vahdati and Lotfi, 2013), they study the effects of different irrigation systems during two stages of growth on total chlorophyll in, total soluble sugars content and antioxidant activity in potato leaves.

The aim of this study was to evaluate the effect of irrigation intervals and some biotic and abiotic treatments on potato yield and quality in two growing spring seasons 2017 and 2018, as well as studding the possibility to reducing water requirements of potato while maintaining the tuber quantities and qualities under the field conditions in Sulaimani - Iraqi Kurdistan region.

\section{Material and methods}

This study carried out in two growing spring seasons 2017 and 2018 in Kanipanka Agricultural Research Station which located in North-East of Iraq (Lat. 35 13 '12", Long. $45^{\circ} 25^{\prime} 48^{\prime \prime}, 550$ MASL) in Shahrazoor valley $35 \mathrm{~km}$ east of Sulaimani. GIS software was used to create the study sites shown in Figure 1. Generally, the elevation of this region ranges between 5 and $2368 \mathrm{~m}$ above sea levels. This study includes the interaction effect of two irrigation intervals (5 and 10 days) and thirteen treatments such as Glycyrrhiza glabra extract, potassium chloride $(\mathrm{KCl})$, and mycorrhiza inoculation and their interaction on yield quantity and quality of potato plant under field condition. The climate of the study area is generally characterized by warm, dry summer and cold winters (Najmaddin et al., 2017). Thus, the meteorological data of Kanipanka during both growing seasons are shown in Table 1. Some physical and chemical properties of Kanipanka soil are shown in Table 2. 


\section{Bio inoculation}

The fungal inoculants Glomus mosseae was obtained from Al-Zaefaraniya Agricultural Research Station/Ministry of Science and Technology/Baghdad. The inoculants were consisting of mycorrhiza spore with 47 spores $\mathrm{g}^{-1}$ dry soil and the residual of the infected roots. Potato tubers were inoculated with the mycorrhiza spores by using $20 \mathrm{~g}$ from the mixture of the inoculums and the pet moss inside the pores, which specified for inoculation treatment before planting the tubers where the pad method was used to ensure the infection by touching the inoculums during planting.

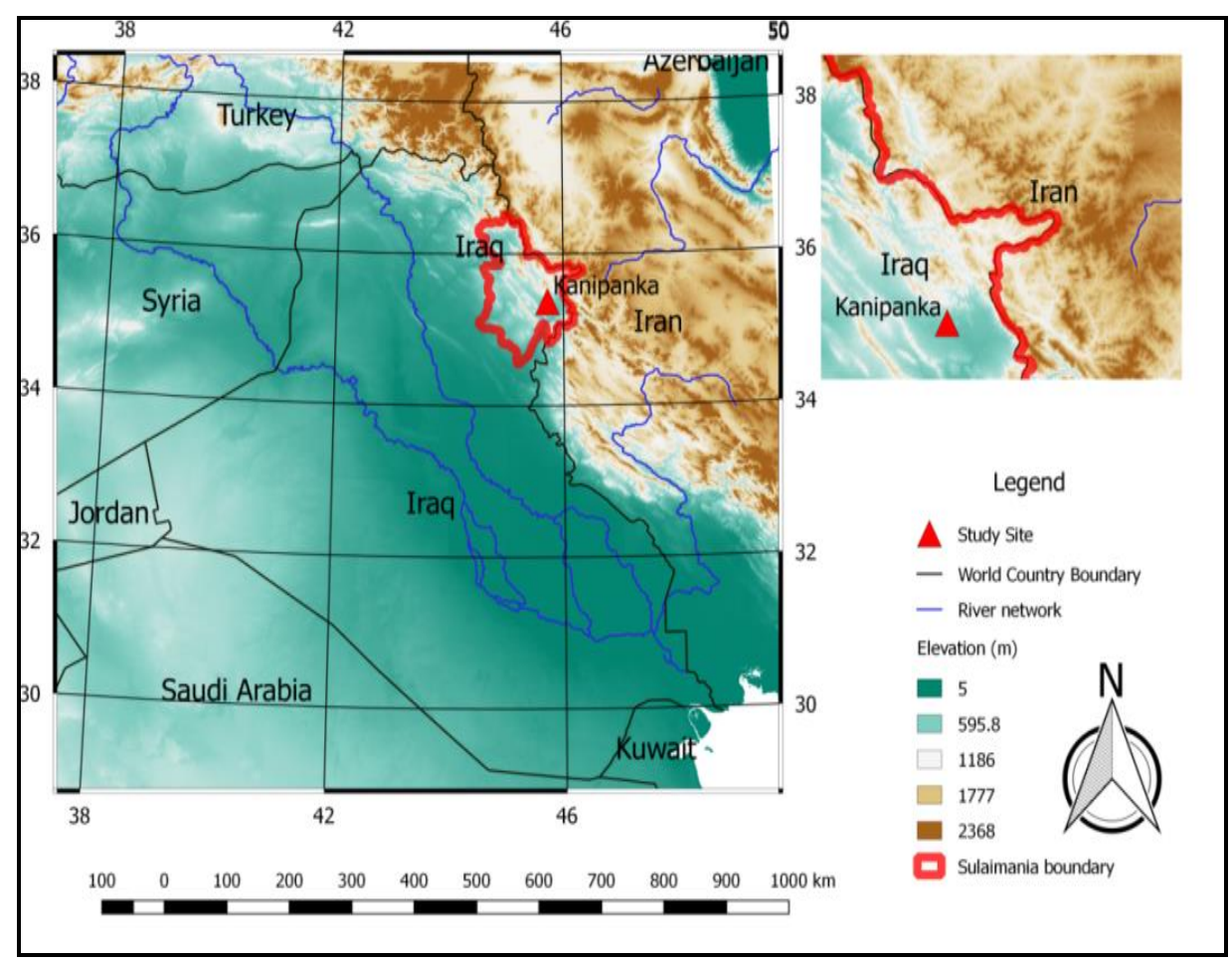

Figure 1. Regional and local location of the study site

Table 1. Meteorological data of Kanipanka location during both growing seasons (2017 and 2018)

\begin{tabular}{|c|c|c|c|c|c|c|c|c|c|}
\hline \multirow{2}{*}{ Months } & \multicolumn{3}{|c|}{ Air temp. $\left({ }^{\circ} \mathrm{C}\right)$} & \multicolumn{3}{|c|}{ Humidity (\%) } & \multirow{2}{*}{$\begin{array}{l}\text { Prec. } \\
(\mathrm{mm})\end{array}$} & \multirow{2}{*}{$\begin{array}{c}\text { Pan eva. } \\
\text { (mm) }\end{array}$} & \multirow{2}{*}{$\begin{array}{c}\text { Soil temp. } \\
\left({ }^{\circ} \mathrm{C}\right)\end{array}$} \\
\hline & Avg. & Max. & Min. & Avg. & Max. & Min. & & & \\
\hline \multicolumn{10}{|c|}{ First season 2017} \\
\hline March & 12.2 & 23.0 & 4.0 & 49.7 & 84.0 & 22.0 & 107.1 & 70.2 & 12.0 \\
\hline April & 17.4 & 31.1 & 7.0 & 42.0 & 79.0 & 17.0 & 39.6 & 119.9 & 17.6 \\
\hline May & 24.6 & 39.3 & 12.2 & 30.3 & 75.0 & 16.0 & 19.3 & 164.4 & 23.9 \\
\hline June & 30.4 & 45.7 & 15.2 & 21.4 & 32.0 & 14.0 & 0.0 & 216.0 & 29.4 \\
\hline \multicolumn{10}{|c|}{ Second season 2018} \\
\hline March & 14.7 & 30.0 & 2.5 & 42.3 & 78.0 & 18.0 & 15.5 & 98.7 & 11.7 \\
\hline April & 17.1 & 29.7 & 6.2 & 38.4 & 80.0 & 17.0 & 82.7 & 110.5 & 17.4 \\
\hline May & 22.2 & 37.8 & 10.0 & 36.1 & 84.0 & 17.0 & 51.8 & 135.1 & 20.6 \\
\hline June & 30.3 & 45.5 & 17.0 & 21.7 & 30.0 & 13.3 & 0.0 & 211.3 & 27.1 \\
\hline
\end{tabular}




$$
-14791 \text { - }
$$

Table 2. Some physical and chemical properties of Kanipanka soil

\begin{tabular}{c|c|c}
\hline Soil components & Quantities & Unit \\
\hline Sand & 308.0 & $\mathrm{~g} \mathrm{~kg}^{-1}$ \\
Silt & 340.0 & $\mathrm{~g} \mathrm{~kg}^{-1}$ \\
Clay & 352.0 & $\mathrm{~g} \mathrm{~kg}^{-1}$ \\
Textured class & Clay loam & \\
pH & 7.10 & \\
EC & 0.38 & $\mathrm{dS} \mathrm{m}^{-1}$ \\
Field capacity & 290.0 & $\mathrm{~g} \mathrm{~kg}^{-1}$ \\
Wilting point & 180.0 & $\mathrm{~g} \mathrm{~kg} \mathrm{~g}^{-1}$ \\
Organic matter & 8.5 & $\mathrm{~g} \mathrm{~kg}^{-1}$ \\
Available nitrogen & 32.0 & $\mathrm{~g} \mathrm{~kg}^{-1}$ \\
Available phosphate & 8.0 & $\mathrm{~g} \mathrm{~kg}^{-1}$ \\
Available potassium & 73.11 & $\mathrm{~g} \mathrm{~kg}^{-1}$ \\
Carbonate minerals & 201.2 & $\mathrm{~g} \mathrm{~kg}^{-1}$ \\
Bulk density & 1.32 & $\mathrm{~g} \mathrm{~cm}^{-3}$ \\
CEC & 33.0 & $\mathrm{cmol} \mathrm{kg}^{-1}$ \\
Calcium (Ca++) & 2.29 & $\mathrm{meq} \mathrm{L}^{-1}$ \\
Magnesium (Mg++) & 2.53 & $\mathrm{meq} \mathrm{L}^{-1}$ \\
Potassium (K+) & 0.93 & $\mathrm{meq} \mathrm{L}^{-1}$ \\
Sodium (Na+) & 2.10 & $\mathrm{meq} \mathrm{L}^{-1}$ \\
Carbonate (CO3=) & $\mathrm{Nil}$ & $\mathrm{meq} \mathrm{L}^{-1}$ \\
Bicarbonate (HCO3-) & 0.90 & $\mathrm{meq} \mathrm{L}^{-1}$ \\
Chloride (Cl-) & 2.49 & $\mathrm{meq} \mathrm{L}^{-1}$ \\
Sulfate (SO4=) & 2.16 & $\mathrm{meq} \mathrm{L}^{-1}$ \\
\hline
\end{tabular}

\section{Preparation of Glycyrrhiza glabra extraction}

Glycyrrhiza glabra roots powder (3 and 6) g was soaked separately in one litter hot distilled water at $50{ }^{\circ} \mathrm{C}$ for $24 \mathrm{~h}$ in dark colure bottles with shaking continuously. The solution filtered through several layers of filter papers, to obtained two concentrations of the extraction 3 and $6 \mathrm{~g} \mathrm{~L}^{-1}$ and several drops of Twin20 were added as a spread material to reduce the surface tension. The plants were sprayed two times 45 and 60 days after planting date, after the sun seat in both years 2017 and 2018 (Lazim and Sulaiman, 2012).

\section{Preparation of potassium fertilizer $(\mathrm{KCl})$}

Two half five gram of potassium chloride $(\mathrm{KCl})$ was dissolved in one liter hot distilled water at $40{ }^{\circ} \mathrm{C}$ with shaking the potassium completely dissolved and several drops of Twin 20 were added as a spreading material to reduce the surface tension. The plants were sprayed at the morning trice 40,55 and 70 days after planting in both years 2017 and 2018.

\section{Addition of chemical fertilizer}

Six hundred kilograms per hectare of Di-Ammonium Phosphate (DAP) 18:18:0 fertilizer was added in two times. The first was during the cultivation of the tubers (spares on the furrows) and the second addition was after one month from the first 
addition as recommended for the chemical fertilizer treatment only (Esho et al., 2009), while half of the recommended were added for the rest of the treatments.

\section{Field practices}

Potato tubers (Acterice varieties) which produced by the Agro-plant's Company/Nederland, used in the study, each experimental unit (furrow) was $3 \mathrm{~m}$ long and $0.8 \mathrm{~m}$ apart $\left(2.4 \mathrm{~m}^{2}\right)$, each furrow consists of 12 plants in one side. Planting dates were 10 March 2017 and 5 March 2018 at the first and the second season respectively, while the harvesting was accomplished after 100 days on 20 June 2017 and 15 June 2018 at the first and the second season respectively. The land was plowed perpendicularly at $30 \mathrm{~cm}$ depth by using moldboard plow then the soil was smoothed by disc harrow then leveled the all the divisions were made to furrow according to the experimental layout (Fig. 2). Each experimental units (furrows) within the blocks were divided into four groups, each group consists of four furrows the last one was one furrow, each group were conducted with a $10 \mathrm{~cm}$ diameter plastic pipes to feeding them with water from the mainstream. Watering timing from the mainstream to the furrows was calculated according to the field design for furrow irrigation system (Fig. 3).

The irrigation timing was computed until the water reached the standardized line in each furrow in order to measure the amount of water that entered each furrow through the plastic pipes in the irrigation intervals ( 5 and 10 days). The amount of water and its operation time were calculated to estimate the discharge of sub main irrigation pipe. Depending on the knowledge discharge, Furrow area, number of furrow, and operation times for irrigation, the depth of irrigation was calculated as well as it can be used to estimate the amount of irrigation (Eq. 1). In 2017, the depth and the amount of irrigation were $369 \mathrm{~mm}$ and $0.885 \mathrm{~m}^{3}$ furrow ${ }^{-1}$ respectively for $\mathbf{I} \mathbf{5}$, while the values were $228 \mathrm{~mm}$ and $0.547 \mathrm{~m}^{3}$ furrow $^{-1}$ respectively for $\mathbf{I}_{10}$. In 2018 , the values were $363 \mathrm{~mm}$ and $0.871 \mathrm{~m}^{3}$ furrow ${ }^{-1}$ respectively for $\mathbf{I}_{5}$, and $287 \mathrm{~mm}$ and $0.668 \mathrm{~m}^{3}$ furrow ${ }^{-1}$ respectively for $\mathbf{I}_{10}$.

$$
Q t=n A d
$$

where: Qt: the amount of irrigation (L), Q: discharge of sub main $\left(\mathrm{L} \mathrm{s}^{-1}\right)$, t: operation time (s), n: No. of the furrows, A: area of the furrow $\left(2.4 \mathrm{~m}^{2}\right)$, d: depth of irrigation water $(\mathrm{mm})$.

\section{Statistical analysis}

A factorial experiment was conducted in a split-plot design with three replicates; the first factor (Irrigation intervals) was implemented in the main plots and conducted with Randomized Complete Block Design (RCBD), while the second factor (Treatments) was implemented in the subplots. All possible comparisons among the means were carried out by using Least Significant Difference (L.S.D) test at a significant level of $5 \%$ after they show their significance in the general test (AL-Rawi and Khalafallah, 1980). The study included treatments as specified in Table 3.

\section{Quantitative and qualitative yield characters}

After tubers maturity harvested were performed manually (100 days from planting date), the yield was calculated (Eq. 2). 


$$
\text { Total Yield }\left(t h a^{-1}\right)=\frac{\text { Yield of the Experimental Unit }(t)}{\text { Area of the Experimental Unit }\left(\mathrm{m}^{2}\right)} \times 10000 \mathrm{~m}^{2}
$$

\section{Total soluble solid (\%)}

Total soluble solids were measured by Refractometer (LCD DIGITAL BENCH MODEL). In order to measure T.S.S. (\%), a drop of the tuber extract was placed on the prism of the digital Refractometer and the total soluble solids were read in Brix (A.O.A.C, 1986).

\section{Tuber starch percentage (\%)}

The percentage of starch was estimated based on the dry weight of the tuber (A. O. A. C. 1970), according to Equation 3.

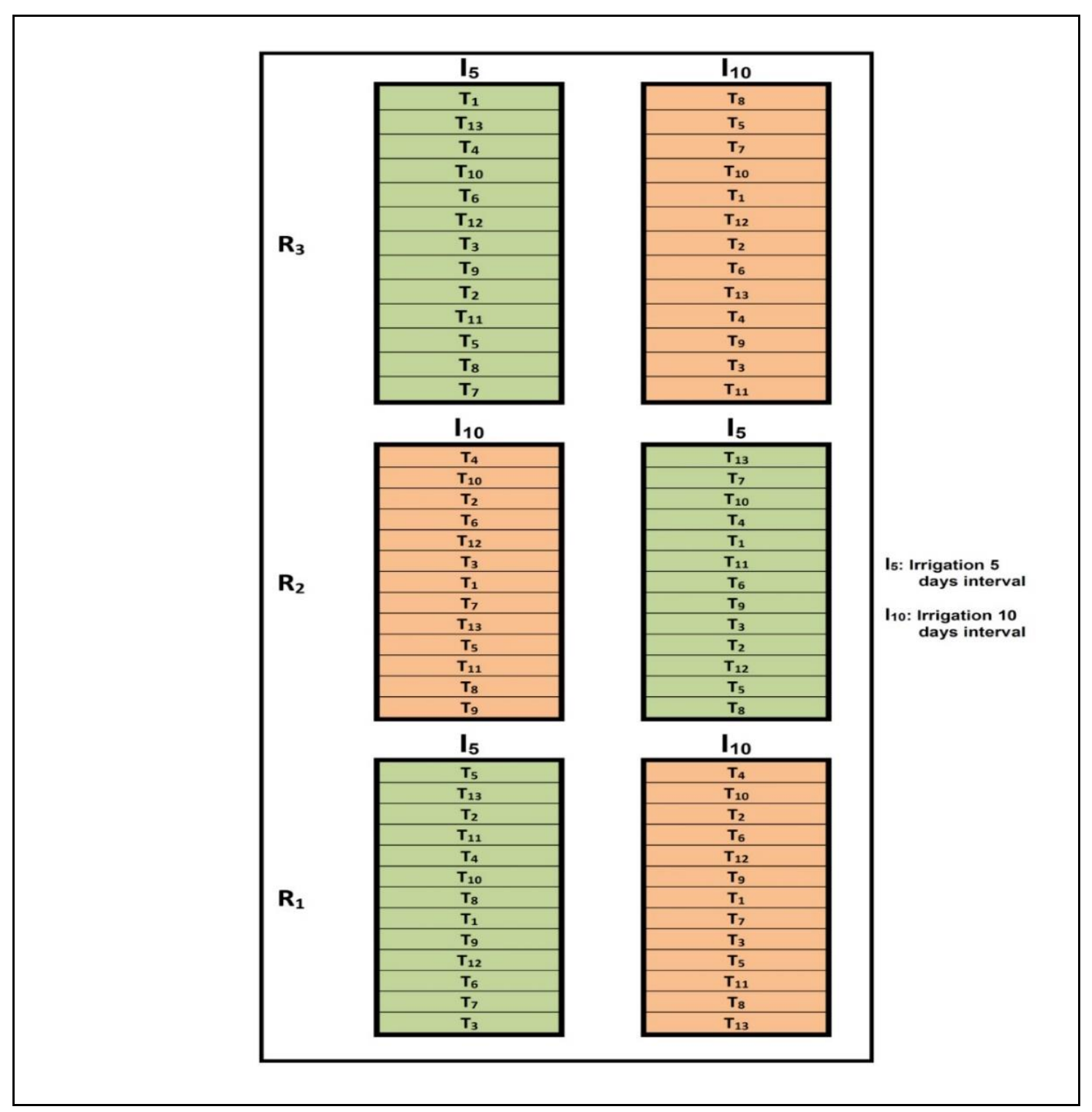

Figure 2. The experimental layout 


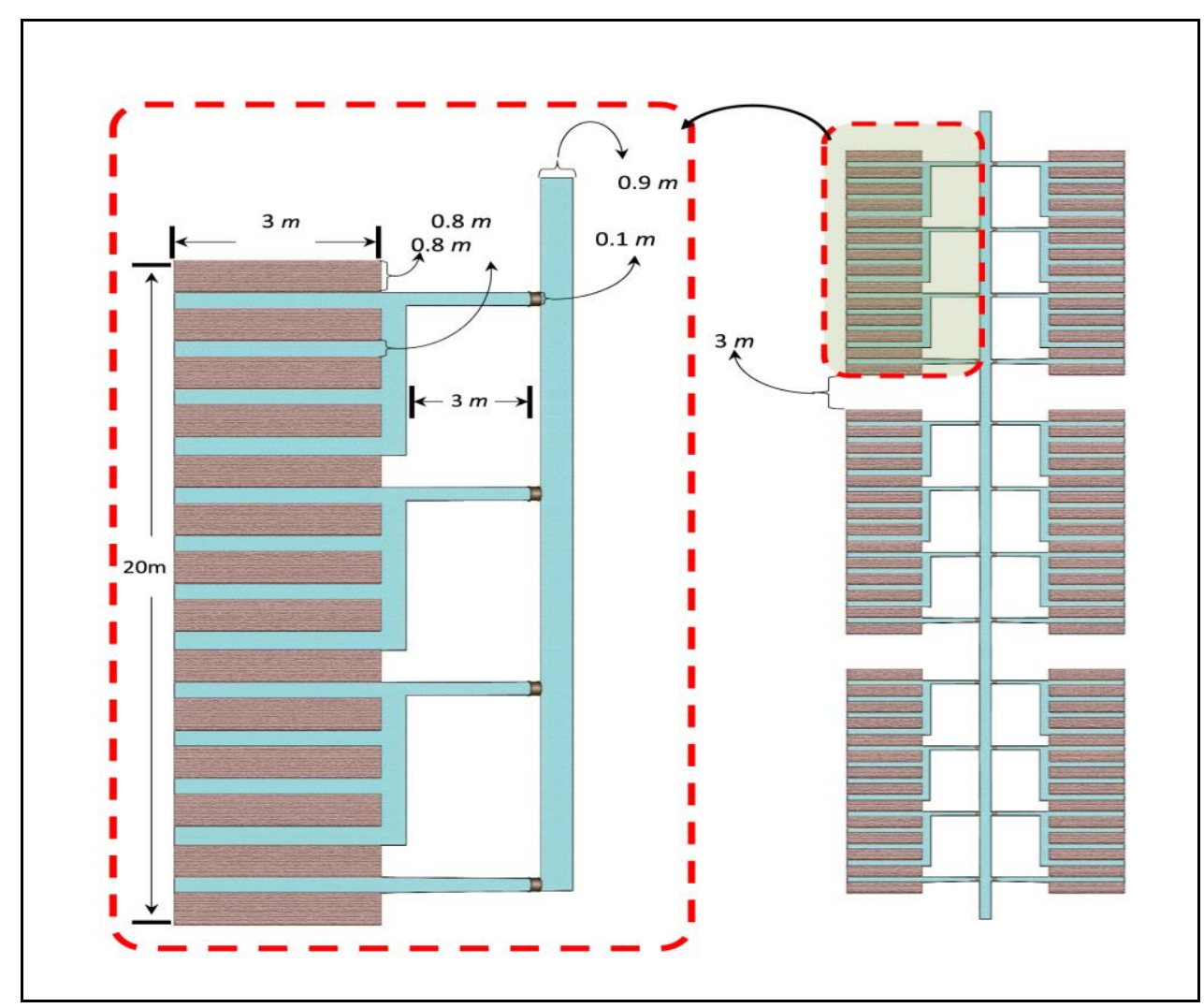

Figure 3. The field design for furrow irrigation system

Table 3. The experimental factors used in the study

\begin{tabular}{|c|c|c|c|}
\hline No. & Factors & Levels & Descriptions \\
\hline \multirow{2}{*}{ First } & \multirow{2}{*}{$\begin{array}{l}\text { Irrigation } \\
\text { intervals }\end{array}$} & $\mathbf{I}_{5}$ & 5 days \\
\hline & & $\mathbf{I}_{10}$ & 10 days \\
\hline \multirow{13}{*}{ Second } & \multirow{13}{*}{ Treatments } & $\mathbf{T}_{\mathbf{1}}$ & Control (spray with distilled water) \\
\hline & & $\mathbf{T}_{2}$ & Di-Ammonium phosphate (DAP) \\
\hline & & $\mathbf{T}_{3}$ & Mycorrhizal inoculation \\
\hline & & $\mathbf{T}_{4}$ & Spraying with $\left(2.5 \mathrm{~g} \mathrm{~L}^{-1}\right) \mathrm{KCl}$ \\
\hline & & $\mathbf{T}_{5}$ & Spraying with $\left(3 \mathrm{~g} \mathrm{~L}^{-1}\right)$ Glycyrrhiza glabra extract \\
\hline & & $\mathbf{T}_{6}$ & Spraying with $\left(6 \mathrm{~g} \mathrm{~L}^{-1}\right)$ Glycyrrhiza glabra extract \\
\hline & & $\mathbf{T}_{7}$ & Mycorrhizal Inoculation + spraying with $\left(2.5 \mathrm{~g} \mathrm{~L}^{-1}\right) \mathrm{KCl}$ \\
\hline & & T8 & $\begin{array}{l}\text { Mycorrhizal Inoculation }+ \text { spraying with }\left(3 \mathrm{~g} \mathrm{~L}^{-1}\right) \text { Glycyrrhiza } \\
\text { glabra extract }\end{array}$ \\
\hline & & T9 & $\begin{array}{l}\text { Mycorrhizal Inoculation + spraying with }\left(6 \mathrm{~g} \mathrm{~L}^{-1}\right) \text { Glycyrrhiza } \\
\text { glabra extract }\end{array}$ \\
\hline & & $\mathbf{T}_{10}$ & $\begin{array}{c}\text { Spraying with }\left(2.5 \mathrm{~g} \mathrm{~L}^{-1}\right) \mathrm{KCl}+\text { spraying with }\left(3 \mathrm{~g} \mathrm{~L}^{-1}\right) \\
\text { Glycyrrhiza glabra extract }\end{array}$ \\
\hline & & $\mathbf{T}_{11}$ & $\begin{array}{l}\text { Spraying with }\left(2.5 \mathrm{~g} \mathrm{~L}^{-1}\right) \mathrm{KCl}+\text { spraying with }\left(6 \mathrm{~g} \mathrm{~L}^{-1}\right) \\
\text { Glycyrrhiza glabra extract }\end{array}$ \\
\hline & & $\mathbf{T}_{12}$ & $\begin{array}{l}\text { Mycorrhizal Inoculation + spraying with }\left(2.5 \mathrm{~g} \mathrm{~L}^{-1}\right) \mathrm{KCl} \\
+ \text { spraying with }\left(3 \mathrm{~g} \mathrm{~L}^{-1}\right) \text { Glycyrrhiza glabra extract }\end{array}$ \\
\hline & & $\mathbf{T}_{13}$ & $\begin{array}{l}\text { Mycorrhizal Inoculation + spraying with }\left(2.5 \mathrm{~g} \mathrm{~L}^{-1}\right) \mathrm{KCl} \\
+ \text { spraying with }\left(6 \mathrm{~g} \mathrm{~L}^{-1}\right) \text { Glycyrrhiza glabra extract }\end{array}$ \\
\hline
\end{tabular}




$$
-14795-
$$

\section{Analysis and estimation of some amino acids in potato tubers}

Amino acids in tubers were estimated and analyzed using High-Performance Liquid Chromatography (YL9100 HPLC System, Model: YL9101 Vacuum Degasser, S/N: D2714120911, YL: instrument CO. LTD, made in Korea) device in potato tubers. Five grams from the tubers mixed with the methanol and water in 10:40 ratio respectively. The mixture was filtered using fine Tapestry cloth, then the precipitated leach was stored in a sterile bottle $\left(-20{ }^{\circ} \mathrm{C}\right)$ (Itakura et al., 2001). It is worth to mention that the Orethophthalheide derivative (OPA) was prepared according to (Graser et al., 1985). Approximately $5 \mathrm{mg}$ of the sample was weighed into a $10 \mathrm{ml}$ headspace glass vial with crimp cap and $3 \mathrm{ml}$ hydrochloric acid $(6 \mathrm{M}$ with $0.1 \% \mathrm{w} / \mathrm{v}$ phenol) was added. The vial was sealed and placed in a preheated oven at $110^{\circ} \mathrm{C}$ for $24 \mathrm{~h}$. After hydrolysis, the samples were allowed to cool to handling temperature then neutralized with $3 \mathrm{ml}$ sodium hydroxide $(6 \mathrm{M})$ mixed thoroughly and left to cool to handling temperature. After cooling, an aliquot was filtered through a $0.45 \mu \mathrm{m}, 13 \mathrm{~mm}$ diameter nylon filter (Figs. 4 and 5).

Mobile phase $=$ acetonitrile: buffer (30: 70), Flow $=1 \mathrm{ml} \mathrm{min}^{-1}$

Injection: injection program, including derivatization steps with OPA

Injected volume $=100 \mathrm{uL}$

Column $=$ ZORBAX Eclipse-AAA; $3.5 \mu \mathrm{m} ; \mathrm{L} \times$ i.d. $=150 \times 4.6 \mathrm{~mm}$

Detector: fluorescence $(\mathrm{Ex}=360 \mathrm{~nm}, \mathrm{Em}=450 \mathrm{~nm})$

\section{Results}

Table 4 shows the effects of irrigation intervals on yield quantitative and qualitative characters. The irrigation intervals were significant effects on total yield, total soluble solid (T.S.S\%) in the tuber and all amino acids in the tuber with an exception for Lucien in the first season 2017. The I5 gave the highest values of total yield and T.S.S\% in the tubers with $40.418 \mathrm{t} \mathrm{ha}^{-1}$ and $9.536 \%$, while the $\mathbf{I}_{10}$ gave the minimum values of total yield and T.S.S\% in the tuber with $32.205 \mathrm{t} \mathrm{ha}^{-1}$ and $5.872 \%$, but the $\mathbf{I}_{10}$ gave the highest values for Proline, Glycine, and Lysine with 2.707, 2.681 and $2.861 \mathrm{mg} \mathrm{g}^{-1}$ respectively, and the $\mathbf{I}_{5}$ gave the lowest values with $2.060,2.091$, and $1.882 \mathrm{mg} \mathrm{g}^{-1}$ respectively.

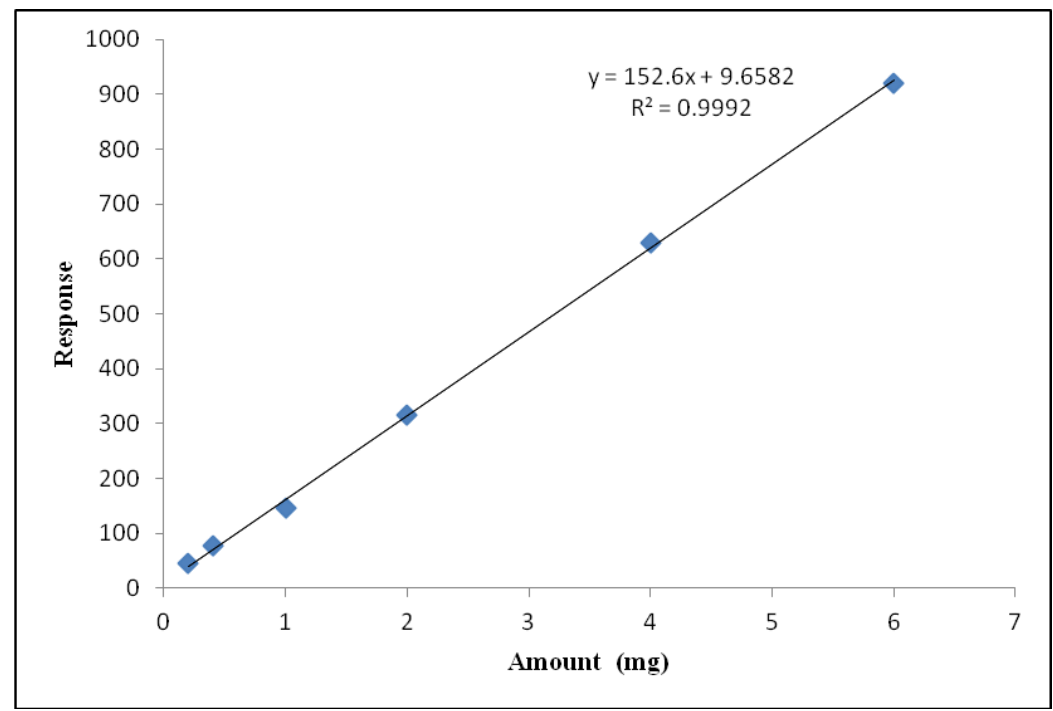

Figure 4. Calibration standard curve of amino acids 


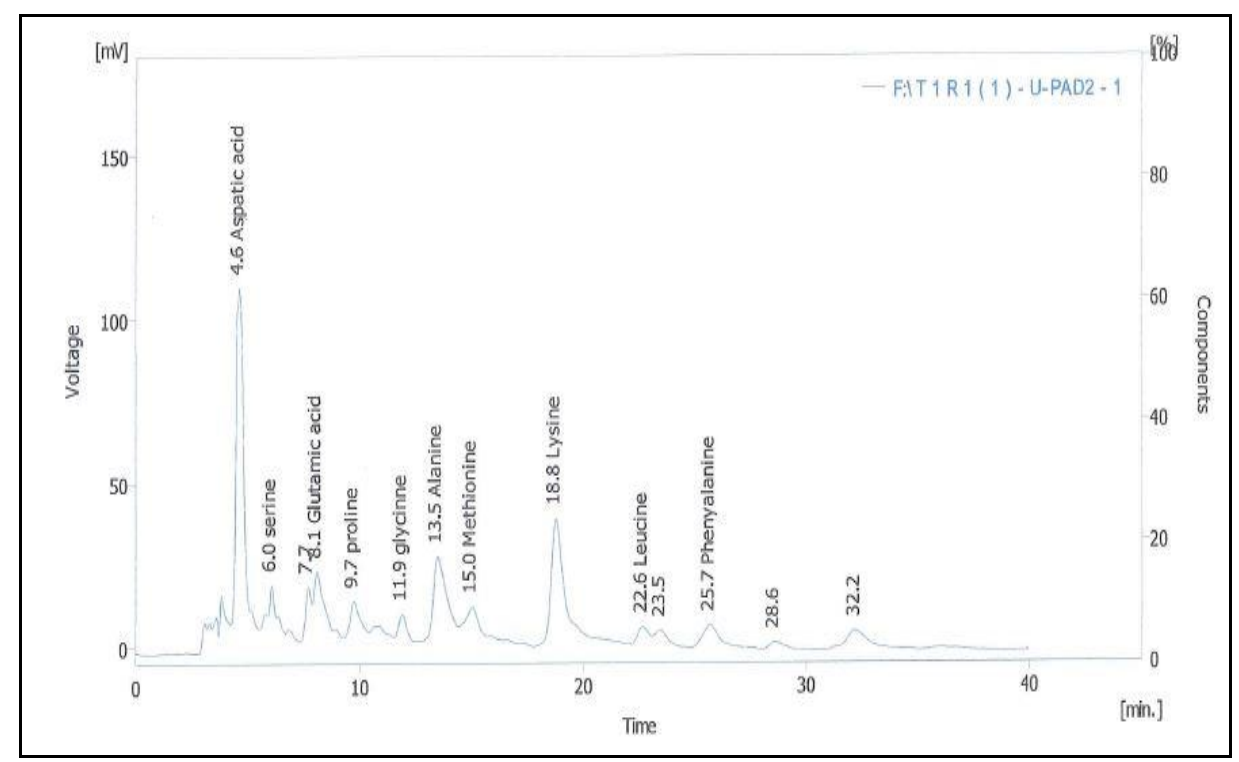

Figure 5. An example of HPLC chromatogram of amino acid profile in potato tubers

Table 4. Effect of irrigation intervals on yield quantitative and qualitative characters at both growing seasons 2017 and 2018

\begin{tabular}{|c|c|c|c|c|c|c|c|}
\hline $\begin{array}{c}\text { Irrigation } \\
\text { interval (A) }\end{array}$ & $\begin{array}{c}\text { Total yield } \\
\left(\mathrm{t} \mathrm{ha}^{-1}\right)\end{array}$ & $\begin{array}{c}\text { T.S.S } \\
(\%)\end{array}$ & $\begin{array}{c}\text { Starch } \\
(\%)\end{array}$ & Proline & Glycine & Lucien & Lysine \\
\hline \multicolumn{8}{|c|}{ First season 2017} \\
\hline$I_{5}$ & 40.418 a & $9.536 \mathrm{a}$ & $21.392 \mathrm{a}$ & $2.060 \mathrm{~b}$ & $2.091 \mathrm{~b}$ & $2.659 \mathrm{a}$ & $1.882 \mathrm{~b}$ \\
\hline $\mathbf{I}_{10}$ & $32.205 \mathrm{~b}$ & $5.872 \mathrm{~b}$ & $23.570 \mathrm{a}$ & $2.707 \mathrm{a}$ & $2.681 \mathrm{a}$ & $2.778 \mathrm{a}$ & $2.861 \mathrm{a}$ \\
\hline L.S.D $(p \leq 0.05)$ & 2.012 & 2.856 & n.s & 0.202 & 0.209 & n.s & 0.220 \\
\hline \multicolumn{8}{|c|}{ Second season 2018} \\
\hline $\mathbf{I}_{5}$ & $42.886 \mathrm{a}$ & $8.479 \mathrm{a}$ & $21.751 \mathrm{a}$ & $2.091 \mathrm{~b}$ & $1.991 \mathrm{~b}$ & $2.656 \mathrm{a}$ & $1.942 \mathrm{~b}$ \\
\hline $\mathbf{I}_{10}$ & $31.431 \mathrm{~b}$ & $6.954 \mathrm{a}$ & $22.281 \mathrm{a}$ & $2.681 \mathrm{a}$ & $2.988 \mathrm{a}$ & $2.816 \mathrm{a}$ & $2.951 \mathrm{a}$ \\
\hline L.S.D $(p \leq 0.05)$ & 4.117 & n.s & n.s & 0.209 & 0.311 & n.s & 0.191 \\
\hline
\end{tabular}

Concerning the second season 2018, the irrigation intervals had a significant effect on total yield, Proline, Glycine, and Lysine character. The I5 gave the highest values for total yield with $42.886 \mathrm{t} \mathrm{ha}^{-1}$, while the lowest values gave by $\mathbf{I} 10$ with $31.431 \mathrm{t} \mathrm{ha}^{-1}$. The I10 achieved the highest values for Proline, Glycine, and Lysine with 2.681, 2.988, and $2.951 \mathrm{mg} \mathrm{g}^{-1}$ respectively. The lowest values achieved by I5 with $2.091,1.991$ and $1.942 \mathrm{mg} \mathrm{g}^{-1}$ respectively.

Table $5 \mathrm{~A}$ illustrates the effects of treatments on yield quantitative and qualitative characters in the first season 2017; data shows the treatments were significant effect for all characters with the exception of starch\% in the tuber. The highest values of total yield gave by $\mathbf{T}_{\mathbf{3}}$ with $44.912 \mathrm{t} \mathrm{ha}^{-1}$. The minimum values obtained by $\mathbf{T}_{\mathbf{1}}$ with $25.984 \mathrm{t} \mathrm{ha}^{-1}$. And the maximum values of T.S.S\% in the tube achieved in $\mathbf{T}_{4}$ with $8.925 \%$. The minimum values of T.S.S\% in tuber were achieved in $\mathbf{T}_{10}$ with $6.592 \%$. The highest values of Proline, Glycine, Lucien, and Lysine in the tuber gave by $\mathbf{T}_{\mathbf{9}}$ with $5.906,5.823,6.104$ and $6.143 \mathrm{mg} \mathrm{g}^{-1}$ respectively. The minimum values were recorded by $\mathbf{T}_{1}$ with $0.241,0.211,0.293$ and $0.126 \mathrm{mg} \mathrm{g}^{-1}$ respectively. 


$$
\text { - } 14797 \text { - }
$$

Table 5A. Effect of the treatments on yield quantitative and qualitative characters in the first season 2017

\begin{tabular}{c|c|c|c|c|c|c|c}
\hline $\mathbf{T}_{\mathbf{i}}$ & $\begin{array}{c}\text { Total yield } \\
\left.\mathbf{( t ~ h a - 1}^{-1}\right)\end{array}$ & $\begin{array}{c}\text { T.S.S } \\
(\boldsymbol{\%})\end{array}$ & $\begin{array}{c}\text { Starch } \\
(\boldsymbol{\%})\end{array}$ & Proline & Glycine & Lucien & Lysine \\
\hline $\mathbf{T}_{\mathbf{1}}$ & $25.984 \mathrm{~d}$ & $7.017 \mathrm{~d}$ & $23.178 \mathrm{a}$ & $0.241 \mathrm{j}$ & $0.211 \mathrm{~h}$ & $0.293 \mathrm{~h}$ & $0.126 \mathrm{~h}$ \\
$\mathbf{T}_{\mathbf{2}}$ & $38.984 \mathrm{~b}$ & $7.875 \mathrm{bc}$ & $23.101 \mathrm{a}$ & $0.506 \mathrm{hi}$ & $0.360 \mathrm{gh}$ & $0.462 \mathrm{gh}$ & $0.267 \mathrm{~h}$ \\
$\mathbf{T}_{\mathbf{3}}$ & $44.912 \mathrm{a}$ & $8.292 \mathrm{ab}$ & $22.359 \mathrm{a}$ & $0.559 \mathrm{gh}$ & $0.546 \mathrm{gh}$ & $0.536 \mathrm{gh}$ & $0.408 \mathrm{~h}$ \\
$\mathbf{T}_{\mathbf{4}}$ & $37.634 \mathrm{~b}$ & $8.925 \mathrm{ab}$ & $20.402 \mathrm{a}$ & $0.289 \mathrm{ij}$ & $0.286 \mathrm{~h}$ & $0.414 \mathrm{gh}$ & $0.165 \mathrm{~h}$ \\
$\mathbf{T}_{\mathbf{5}}$ & $31.654 \mathrm{~cd}$ & $8.658 \mathrm{ab}$ & $25.498 \mathrm{a}$ & $2.774 \mathrm{e}$ & $2.629 \mathrm{e}$ & $3.727 \mathrm{~d}$ & $3.027 \mathrm{e}$ \\
$\mathbf{T}_{\mathbf{6}}$ & $37.812 \mathrm{~b}$ & $7.075 \mathrm{~d}$ & $23.404 \mathrm{a}$ & $3.257 \mathrm{~d}$ & $3.426 \mathrm{~d}$ & $4.397 \mathrm{c}$ & $3.672 \mathrm{~d}$ \\
$\mathbf{T}_{\mathbf{7}}$ & $39.331 \mathrm{ab}$ & $6.908 \mathrm{~d}$ & $22.407 \mathrm{a}$ & $0.747 \mathrm{~g}$ & $0.811 \mathrm{~g}$ & $0.896 \mathrm{~g}$ & $0.720 \mathrm{~g}$ \\
$\mathbf{T}_{\mathbf{8}}$ & $36.033 \mathrm{bc}$ & $7.225 \mathrm{~cd}$ & $22.426 \mathrm{a}$ & $4.044 \mathrm{c}$ & $4.269 \mathrm{c}$ & $5.596 \mathrm{~b}$ & $5.087 \mathrm{~b}$ \\
$\mathbf{T}_{\mathbf{9}}$ & $33.924 \mathrm{bc}$ & $7.892 \mathrm{bc}$ & $23.131 \mathrm{a}$ & $5.906 \mathrm{a}$ & $5.823 \mathrm{a}$ & $6.104 \mathrm{a}$ & $6.143 \mathrm{a}$ \\
$\mathbf{T}_{\mathbf{1 0}}$ & $36.347 \mathrm{bc}$ & $6.592 \mathrm{~d}$ & $23.135 \mathrm{a}$ & $1.667 \mathrm{f}$ & $1.553 \mathrm{f}$ & $1.419 \mathrm{f}$ & $1.358 \mathrm{f}$ \\
$\mathbf{T}_{\mathbf{1 1}}$ & $36.856 \mathrm{bc}$ & $6.992 \mathrm{~d}$ & $20.470 \mathrm{a}$ & $2.279 \mathrm{e}$ & $2.184 \mathrm{e}$ & $2.256 \mathrm{e}$ & $1.620 \mathrm{f}$ \\
$\mathbf{T}_{\mathbf{1 2}}$ & $36.293 \mathrm{bc}$ & $8.408 \mathrm{ab}$ & $21.253 \mathrm{a}$ & $4.050 \mathrm{c}$ & $4.107 \mathrm{c}$ & $3.834 \mathrm{~d}$ & $3.667 \mathrm{~d}$ \\
$\mathbf{T}_{\mathbf{1 3}}$ & $36.284 \mathrm{bc}$ & $8.292 \mathrm{ab}$ & $21.484 \mathrm{a}$ & $4.665 \mathrm{~b}$ & $4.814 \mathrm{~b}$ & $5.406 \mathrm{~b}$ & $4.567 \mathrm{c}$ \\
\hline LSD $_{(\mathbf{p} \leq \mathbf{0 . 0 5})}$ & $\mathbf{5 . 9 4 0}$ & $\mathbf{0 . 7 9 9}$ & $\mathbf{n . s}$ & $\mathbf{0 . 2 2 5}$ & $\mathbf{0 . 4 5 3}$ & $\mathbf{0 . 4 9 6}$ & $\mathbf{0 . 3 0 5}$ \\
\hline
\end{tabular}

Table $5 \mathrm{~A}$ illustrates the effects of treatments on yield quantitative and qualitative characters in the first season 2017; data shows the treatments were significant effect for all characters with the exception of starch\% in the tuber. The highest values of total yield gave by $\mathbf{T}_{\mathbf{3}}$ with $44.912 \mathrm{t} \mathrm{ha}^{-1}$. The minimum values obtained by $\mathbf{T}_{\mathbf{1}}$ with $25.984 \mathrm{t} \mathrm{ha}^{-1}$. And the maximum values of T.S.S\% in the tube achieved in $\mathbf{T}_{\mathbf{4}}$ with $8.925 \%$. The minimum values of T.S.S\% in tuber were achieved in $\mathbf{T}_{10}$ with $6.592 \%$. The highest values of Proline, Glycine, Lucien, and Lysine in the tuber gave by $\mathbf{T}_{\mathbf{9}}$ with $5.906,5.823,6.104$ and $6.143 \mathrm{mg} \mathrm{g}^{-1}$ respectively. The minimum values were recorded by $\mathbf{T}_{1}$ with $0.241,0.211,0.293$ and $0.126 \mathrm{mg} \mathrm{g}^{-1}$ respectively.

Table $5 B$ shows the effect of the treatments on yield quantitative and qualitative characters in the second season 2018, the statistical analysis reveals a significant difference for all of the characters. The highest values of total yield gave by $\mathbf{T} 11$ with $42.106 \mathrm{t} / \mathrm{ha}$. The minimum values obtained by $\mathbf{T}_{\mathbf{1}}$ with $29.678 \mathrm{t} \mathrm{ha}^{-1}$. And the maximum values for T.S.S\% were given by $\mathbf{T}_{\mathbf{4}}$ with $9.083 \%$. The minimum values were given by $\mathbf{T}_{\mathbf{5}}$ with $6.450 \%$. Regarding the starch\% in the tuber, the $\mathbf{T}_{\mathbf{1}}$ gave the highest values with $26.948 \%$. The lowest values obtained by treatments $\mathbf{T}_{13}$ with $18.222 \%$. The maximum values of Proline, Lucien and Lysine were obtained by $\mathbf{T} 9$ with 5.823, 4.971 and $6.096 \mathrm{mg} \mathrm{g}^{-1}$ respectively. Whereas the maximum values for Glycine were recorded by $\mathbf{T}_{\mathbf{8}}$ with $5.596 \mathrm{mg} \mathrm{g}^{-1}$. The minimum values were recorded by $\mathbf{T}_{\mathbf{1}}$ with $0.211,0.222$, 0.289 and $0.106 \mathrm{mg} \mathrm{g}^{-1}$ for Proline, Glycine, Lucien, and Lysine respectively.

Table $6 A$ shows the interaction effects of irrigation intervals and treatments on yield quantitative and qualitative characters at the first season 2017, the statistical analysis reveals significant difference for T.S.S\% and amino acid in the tubers (Proline, Glycine, Lucien, and Lysine). The highest values for T.S.S\% was obtained in the interaction of $\mathbf{I}_{5} \times \mathbf{T}_{\mathbf{1 3}}$ with $11.200 \%$. The lowest values obtained in interaction $\mathbf{I}_{10}$ $\times$ T8 with $4.250 \%$, and the highest values of Proline, Glycine, and Lysine gave by interaction $\mathbf{I}_{10} \times \mathbf{T}_{13}$ with $6.724,6.912$ and $7.525 \mathrm{mg} \mathrm{g}^{-1}$ respectively. But the 
maximum values of Lucien recorded by $\mathbf{I} 5 \times \mathbf{T} \mathbf{9}$ with $6.148 \mathrm{mg} \mathrm{g}^{-1}$. The minimum values were recorded by $\mathbf{I} \times \mathbf{T} \mathbf{T}$ with $0.143,0.126,0.284$ and $0.080 \mathrm{mg} \mathrm{g}^{-1}$ respectively for Proline, Glycine, Lucien, and Lysine.

Table 5B. Effect of the treatments on yield quantitative and qualitative characters in the second season 2018

\begin{tabular}{c|c|c|c|c|c|c|c}
\hline $\mathbf{T}_{\mathbf{i}}$ & $\begin{array}{c}\text { Total yield } \\
(\mathbf{t ~ h a - 1})\end{array}$ & $\begin{array}{c}\text { T.S.S } \\
(\boldsymbol{\%})\end{array}$ & $\begin{array}{c}\text { Starch } \\
(\boldsymbol{\%})\end{array}$ & Proline & Glycine & Lucien & Lysine \\
\hline $\mathbf{T}_{\mathbf{1}}$ & $29.678 \mathrm{e}$ & $7.217 \mathrm{~cd}$ & $26.948 \mathrm{a}$ & $0.211 \mathrm{~h}$ & $0.222 \mathrm{~h}$ & $0.289 \mathrm{~h}$ & $0.106 \mathrm{~h}$ \\
$\mathbf{T}_{\mathbf{2}}$ & $39.809 \mathrm{abc}$ & $7.983 \mathrm{bc}$ & $23.174 \mathrm{~b}$ & $0.360 \mathrm{gh}$ & $0.371 \mathrm{~h}$ & $0.477 \mathrm{~h}$ & $0.290 \mathrm{~h}$ \\
$\mathbf{T}_{\mathbf{3}}$ & $41.453 \mathrm{ab}$ & $8.500 \mathrm{ab}$ & $23.725 \mathrm{ab}$ & $0.546 \mathrm{gh}$ & $0.528 \mathrm{~h}$ & $0.599 \mathrm{gh}$ & $0.385 \mathrm{~h}$ \\
$\mathbf{T}_{\mathbf{4}}$ & $33.424 \mathrm{cde}$ & $9.083 \mathrm{a}$ & $21.741 \mathrm{~b}$ & $0.286 \mathrm{~h}$ & $0.284 \mathrm{~h}$ & $0.373 \mathrm{~h}$ & $0.176 \mathrm{~h}$ \\
$\mathbf{T}_{\mathbf{5}}$ & $34.799 \mathrm{~b}-\mathrm{e}$ & $6.450 \mathrm{~d}$ & $21.621 \mathrm{bc}$ & $2.629 \mathrm{e}$ & $3.317 \mathrm{~d}$ & $3.759 \mathrm{~d}$ & $2.855 \mathrm{e}$ \\
$\mathbf{T}_{\mathbf{6}}$ & $38.924 \mathrm{a}-\mathrm{d}$ & $7.833 \mathrm{bc}$ & $22.256 \mathrm{~b}$ & $3.426 \mathrm{~d}$ & $3.601 \mathrm{~d}$ & $4.375 \mathrm{c}$ & $3.652 \mathrm{~d}$ \\
$\mathbf{T}_{\mathbf{7}}$ & $41.351 \mathrm{ab}$ & $7.367 \mathrm{~cd}$ & $20.429 \mathrm{bc}$ & $0.811 \mathrm{~g}$ & $0.876 \mathrm{~g}$ & $0.966 \mathrm{fg}$ & $0.865 \mathrm{~g}$ \\
$\mathbf{T}_{\mathbf{8}}$ & $34.564 \mathrm{~b}-\mathrm{e}$ & $7.367 \mathrm{~cd}$ & $21.045 \mathrm{bc}$ & $4.269 \mathrm{c}$ & $5.596 \mathrm{a}$ & $5.757 \mathrm{ab}$ & $5.458 \mathrm{~b}$ \\
$\mathbf{T}_{\mathbf{9}}$ & $32.142 \mathrm{de}$ & $7.567 \mathrm{bc}$ & $22.638 \mathrm{~b}$ & $5.823 \mathrm{a}$ & $5.448 \mathrm{a}$ & $6.021 \mathrm{a}$ & $6.096 \mathrm{a}$ \\
$\mathbf{T}_{\mathbf{1 0}}$ & $40.014 \mathrm{abc}$ & $7.850 \mathrm{bc}$ & $21.807 \mathrm{~b}$ & $1.553 \mathrm{f}$ & $1.388 \mathrm{f}$ & $1.442 \mathrm{f}$ & $1.244 \mathrm{~g}$ \\
$\mathbf{T}_{\mathbf{1 1}}$ & $42.106 \mathrm{a}$ & $7.700 \mathrm{bc}$ & $21.904 \mathrm{~b}$ & $2.184 \mathrm{e}$ & $2.047 \mathrm{e}$ & $2.291 \mathrm{e}$ & $1.844 \mathrm{f}$ \\
$\mathbf{T}_{\mathbf{1 2}}$ & $36.089 \mathrm{a}-\mathrm{e}$ & $7.650 \mathrm{bc}$ & $20.699 \mathrm{bc}$ & $4.107 \mathrm{c}$ & $4.079 \mathrm{c}$ & $3.842 \mathrm{~d}$ & $3.916 \mathrm{~d}$ \\
$\mathbf{T}_{\mathbf{1 3}}$ & $38.709 \mathrm{a}-\mathrm{d}$ & $7.750 \mathrm{bc}$ & $18.222 \mathrm{c}$ & $4.814 \mathrm{~b}$ & $4.604 \mathrm{~b}$ & $5.376 \mathrm{~b}$ & $4.918 \mathrm{c}$ \\
\hline $\mathbf{L S D}_{(\mathbf{p} \leq \mathbf{0 . 0 5})}$ & $\mathbf{7 . 3 1 8}$ & $\mathbf{0 . 9 6 1}$ & $\mathbf{3 . 4 7 4}$ & $\mathbf{0 . 4 5 3}$ & $\mathbf{0 . 4 3 5}$ & $\mathbf{0 . 4 8 6}$ & $\mathbf{0 . 4 5 0}$ \\
\hline
\end{tabular}

Data in Table $6 B$ illustrates the interaction effects of irrigation intervals and treatments on yield quantitative and qualitative characters at the second season 2018, the interaction had the significant effect on T.S.S, starch and amino acid in the tuber. The highest values of T.S.S were obtained by interaction $\mathbf{I}_{5} \times \mathbf{T}_{\mathbf{4}}$ with $10.767 \%$. But the lowest values obtained by interaction $\mathrm{I}_{10} \times$ with $6.167 \%$. Regarding on percentage of starch in the tuber, the highest values were achieved by $\mathbf{I}_{\mathbf{5}} \times \mathbf{T}_{\mathbf{1}}$ with $28.226 \%$, the minimum values achieved by $\mathbf{I}_{10} \times \mathbf{T}_{\mathbf{1 3}}$ with $15.964 \%$. The highest values gave by interaction $\mathbf{I}_{10} \times \mathbf{T}$ 9 Proline, and Lysine with 6.912 and $7.290 \mathrm{mg} \mathrm{g}^{-1}$ respectively. And the maximum values for Glycine recorded by interaction with $\mathbf{I}_{10} \times \mathbf{T}_{\mathbf{8}}$ with $7.181 \mathrm{mg} \mathrm{g}^{-}$ ${ }^{1}$. The maximum values of Lucien gave by interaction $\mathbf{I} 5 \times \mathbf{T} 9$ with $6.094 \mathrm{mg} \mathrm{g}^{-1}$, while the minimum values for all amino acid with exception Glycine were recorded by interaction $\mathbf{I}_{5} \times \mathbf{T}_{1}$ with $0.126,0.252$ and $0.079 \mathrm{mg} \mathrm{g}^{-1}$ respectively. But the minimum values of Glycine gave by interaction $\mathbf{I}_{10} \times \mathbf{T}_{\mathbf{1}}$ with $0.198 \mathrm{mg} \mathrm{g}^{-1}$.

Table 7 shows the effect of seasons on yield quantitative and qualitative characters. The season had no significant effects on yield qualitative characters.

\section{Discussion}

Water is one of the most essential elements in growing plants, which constitutes more than $80 \%$ of the active cells. Thereby, the amount of applied water during crop irrigation, added time, irrigation methods, quality of added water, and prevailing micrometeorological conditions have found to play limited roles in yield quality and quantity. In Asia, statistics showed that the yields for most crops have increased 100-400\% after 
irrigation. In the first season of irrigation intervals (5 and 10 days) were applied after 50 days from sowing and were ended at 96 days after sowing, since, the amount of irrigation water for 5 days interval was cover the most of depleted water at this time. The cumulative depth of irrigation for 5 and 10 days from (10 May 2017 to 15 June 2017) were practically measured and formed to be (369 and $228 \mathrm{~mm}$ ) respectively. Since the numbers of irrigation were 10 and 6 times for 5 and 10 days of irrigation intervals respectively, while the amount of actual evapotranspiration for 2017 and 2018 was $(529,423,515$ and $440 \mathrm{~mm})$ respectively, while the cumulate depth of irrigation and precipitation were (535 and $394 \mathrm{~mm}$ ) respectively.

Table 6A. Interaction effects of irrigation intervals and treatments on yield quantitative and qualitative characters in the first season 2017

\begin{tabular}{|c|c|c|c|c|c|c|c|}
\hline $\begin{array}{l}\mathbf{I}_{\mathbf{i}} \times \mathbf{T}_{\mathbf{i}} \\
(\mathbf{A} \times \mathbf{B})\end{array}$ & $\begin{array}{c}\text { Total yield } \\
\left(\mathrm{t} \mathrm{ha}^{-1}\right)\end{array}$ & $\begin{array}{l}\text { T.S.S } \\
(\%)\end{array}$ & $\begin{array}{c}\text { Starch } \\
(\%)\end{array}$ & Proline & Glycine & Lucien & Lysine \\
\hline $\mathbf{I}_{5} \times \mathbf{T}_{1}$ & $28.472 \mathrm{a}$ & $8.033 \mathrm{fg}$ & $23.013 \mathrm{a}$ & $0.143 n$ & $0.126 \mathrm{n}$ & 0.2841 & $0.080 \mathrm{n}$ \\
\hline $\mathbf{I}_{5} \times \mathbf{T}_{2}$ & $44.353 \mathrm{a}$ & $9.233 \mathrm{cde}$ & $23.473 \mathrm{a}$ & $0.228 \mathrm{n}$ & $0.186 \mathrm{n}$ & $0.388 \mathrm{kl}$ & $0.226 \mathrm{mn}$ \\
\hline $\mathbf{I}_{5} \times \mathbf{T}_{\mathbf{3}}$ & $52.324 \mathrm{a}$ & $10.000 \mathrm{bcd}$ & 20.229 a & $0.382 \mathrm{mn}$ & $0.394 \mathrm{mn}$ & $0.502 \mathrm{jkl}$ & $0.452 \mathrm{mn}$ \\
\hline $\mathbf{I}_{5} \times \mathbf{T}_{4}$ & $42.859 \mathrm{a}$ & $10.500 \mathrm{ab}$ & 19.357 a & $0.151 \mathrm{n}$ & $0.159 \mathrm{n}$ & 0.3101 & $0.126 \mathrm{mn}$ \\
\hline $\mathbf{I}_{5} \times \mathbf{T}_{\mathbf{5}}$ & $33.840 \mathrm{a}$ & $9.800 \mathrm{bcd}$ & $23.569 \mathrm{a}$ & $2.400 \mathrm{~h}$ & $2.298 \mathrm{ij}$ & $3.844 \mathrm{e}$ & $2.317 \mathrm{~g}$ \\
\hline $\mathbf{I}_{5} \times \mathbf{T}_{6}$ & $43.307 \mathrm{a}$ & $9.700 \mathrm{bcd}$ & $23.147 \mathrm{a}$ & $3.306 \mathrm{f}$ & $3.530 \mathrm{fg}$ & $4.696 \mathrm{~cd}$ & $3.476 \mathrm{f}$ \\
\hline $\mathbf{I}_{5} \times \mathbf{T}_{7}$ & $43.763 \mathrm{a}$ & $9.000 \mathrm{def}$ & $19.040 \mathrm{a}$ & $0.592 \mathrm{klm}$ & $0.624 \mathrm{mn}$ & $0.774 \mathrm{jkl}$ & $0.528 \mathrm{~lm}$ \\
\hline $\mathbf{I}_{5} \times \mathbf{T}_{8}$ & $38.931 \mathrm{a}$ & $10.200 \mathrm{abc}$ & $21.967 \mathrm{a}$ & $4.114 \mathrm{~d}$ & 4.334 cde & $5.670 \mathrm{a}$ & $4.072 \mathrm{e}$ \\
\hline $\mathbf{I}_{5} \times \mathbf{T} \mathbf{9}$ & $37.284 \mathrm{a}$ & $11.200 \mathrm{a}$ & $19.135 \mathrm{a}$ & $5.088 \mathrm{bc}$ & $4.734 \mathrm{~cd}$ & $6.184 \mathrm{a}$ & $4.762 \mathrm{~d}$ \\
\hline $\mathbf{I}_{5} \times \mathbf{T}_{10}$ & 38.657 a & 8.467 efg & $22.443 \mathrm{a}$ & $1.837 \mathrm{i}$ & $1.772 \mathrm{jk}$ & $1.108 \mathrm{ij}$ & $0.930 \mathrm{jk}$ \\
\hline $\mathbf{I}_{5} \times \mathbf{T}_{11}$ & $45.077 \mathrm{a}$ & $8.900 \mathrm{def}$ & $21.206 \mathrm{a}$ & $1.766 \mathrm{ij}$ & $1.869 \mathrm{ijk}$ & $1.814 \mathrm{~h}$ & $1.358 \mathrm{ij}$ \\
\hline $\mathbf{I}_{5} \times \mathbf{T}_{12}$ & 39.642 a & $9.067 \mathrm{def}$ & 20.862 a & $3.118 \mathrm{f}$ & $3.274 \mathrm{fg}$ & $3.104 \mathrm{fg}$ & $2.502 \mathrm{~g}$ \\
\hline $\mathbf{I}_{5} \times \mathbf{T}_{13}$ & $36.923 \mathrm{a}$ & $9.867 \mathrm{bcd}$ & $20.651 \mathrm{a}$ & $3.656 \mathrm{e}$ & $3.886 \mathrm{ef}$ & $5.894 \mathrm{a}$ & $3.632 \mathrm{f}$ \\
\hline $\mathbf{I}_{10} \times \mathbf{T}_{1}$ & $23.496 \mathrm{a}$ & $6.000 \mathrm{jk}$ & $23.344 \mathrm{a}$ & $0.338 \mathrm{mn}$ & $0.296 \mathrm{n}$ & 0.3021 & $0.172 \mathrm{mn}$ \\
\hline $\mathbf{I}_{10} \times \mathbf{T}_{2}$ & $33.615 \mathrm{a}$ & $6.517 \mathrm{ij}$ & $22.730 \mathrm{a}$ & $0.784 \mathrm{k}$ & $0.534 \mathrm{mn}$ & $0.536 \mathrm{jkl}$ & $0.308 \mathrm{mn}$ \\
\hline $\mathbf{I}_{10} \times \mathbf{T}_{3}$ & $37.500 \mathrm{a}$ & $6.583 \mathrm{ij}$ & $24.489 \mathrm{a}$ & $0.736 \mathrm{kl}$ & $0.698 \mathrm{lmn}$ & $0.570 \mathrm{jkl}$ & $0.364 \mathrm{mn}$ \\
\hline $\mathbf{I}_{10} \times \mathbf{T}_{4}$ & $32.410 \mathrm{a}$ & $7.350 \mathrm{ghi}$ & $21.447 \mathrm{a}$ & $0.428 \mathrm{lmn}$ & $0.412 \mathrm{mn}$ & $0.518 \mathrm{jkl}$ & $0.204 \mathrm{mn}$ \\
\hline $\mathbf{I}_{10} \times \mathbf{T}_{5}$ & $29.467 \mathrm{a}$ & $7.517 \mathrm{ghi}$ & $27.426 \mathrm{a}$ & $3.147 \mathrm{f}$ & $2.960 \mathrm{gh}$ & $3.610 \mathrm{ef}$ & 3.738 ef \\
\hline $\mathbf{I}_{10} \times \mathbf{T}_{6}$ & $32.318 \mathrm{a}$ & 4.4501 & $23.661 \mathrm{a}$ & $3.208 \mathrm{f}$ & $3.322 \mathrm{fg}$ & $4.099 \mathrm{de}$ & 3.868 ef \\
\hline $\mathbf{I}_{10} \times \mathbf{T}_{7}$ & $34.900 \mathrm{a}$ & 4.8171 & $25.774 \mathrm{a}$ & $0.902 \mathrm{k}$ & $0.998 \mathrm{~lm}$ & $1.018 \mathrm{jk}$ & $0.912 \mathrm{kl}$ \\
\hline $\mathbf{I}_{10} \times \mathbf{T}_{\mathbf{8}}$ & $33.134 \mathrm{a}$ & 4.2501 & $22.885 \mathrm{a}$ & $3.974 \mathrm{~d}$ & $4.204 \mathrm{de}$ & $5.521 \mathrm{ab}$ & $6.102 \mathrm{~b}$ \\
\hline $\mathbf{I}_{10} \times \mathbf{T}_{9}$ & $30.564 \mathrm{a}$ & 4.5831 & $27.128 \mathrm{a}$ & $6.724 \mathrm{a}$ & $6.912 \mathrm{a}$ & $6.024 \mathrm{a}$ & $7.525 \mathrm{a}$ \\
\hline $\mathbf{I}_{10} \times \mathbf{T}_{10}$ & $34.037 \mathrm{a}$ & 4.7171 & $23.827 \mathrm{a}$ & $1.498 \mathrm{j}$ & $1.334 \mathrm{kl}$ & $1.730 \mathrm{hi}$ & $1.786 \mathrm{hi}$ \\
\hline $\mathbf{I}_{10} \times \mathbf{T}_{11}$ & $28.635 \mathrm{a}$ & $5.083 \mathrm{kl}$ & $19.734 \mathrm{a}$ & $2.792 \mathrm{~g}$ & 2.498 hi & $2.698 \mathrm{~g}$ & $1.882 \mathrm{~h}$ \\
\hline $\mathbf{I}_{10} \times \mathbf{T}_{12}$ & $32.943 \mathrm{a}$ & $7.750 \mathrm{gh}$ & $21.645 \mathrm{a}$ & $4.981 \mathrm{c}$ & $4.940 \mathrm{c}$ & $4.564 \mathrm{~cd}$ & $4.832 \mathrm{~d}$ \\
\hline $\mathbf{I}_{10} \times \mathbf{T}_{13}$ & $35.646 \mathrm{a}$ & $6.717 \mathrm{hij}$ & $22.318 \mathrm{a}$ & $5.674 \mathrm{~b}$ & $5.742 \mathrm{~b}$ & $4.918 \mathrm{bc}$ & $5.502 \mathrm{c}$ \\
\hline L.S.D $(p \leq 0.05)$ & n.s & 1.130 & n.s & 0.318 & 0.641 & 0.701 & 0.431 \\
\hline
\end{tabular}

In the season 2018 the irrigation intervals (5 and 10 days) was applied from the sowing date and were ended at 95 days after sowing, the amount of irrigation water for 5 days interval which cover the most of depleted from (5 March 2018 to 10 June 2018) were practically measured $(363$ and $287 \mathrm{~mm}$ ) respectively. Since the numbers of 
irrigation were 9 and 5 times for 5 and 10 days of irrigation intervals respectively, while accumulate depth irrigation and precipitation were $(513$ and $437 \mathrm{~mm}$ ) respectively. These results are in agreement with the findings of several other kinds of research (Ati et al., 2013; Ati and Nafaou, 2012). Gander and Tanner (1976) showed that mild water stress of -3 to -5 bars greatly reduce leaf expansion in potatoes, and for best tuber yields, a 120-150 day potato crop requires 508-698.5 $\mathrm{mm}$ of the water.

Table $6 \boldsymbol{B}$. Interaction effects of irrigation intervals and treatments on yield quantitative and qualitative characters in the second season 2018

\begin{tabular}{|c|c|c|c|c|c|c|c|}
\hline $\begin{array}{l}\mathbf{I}_{\mathbf{i}} \times \mathbf{T}_{\mathbf{i}} \\
(\mathbf{A} \times \mathbf{B})\end{array}$ & $\begin{array}{l}\text { Total yield } \\
\left(\mathrm{t} \mathrm{ha}^{-1}\right)\end{array}$ & $\begin{array}{l}\text { T.S.S } \\
(\%)\end{array}$ & $\begin{array}{c}\text { Starch } \\
(\%)\end{array}$ & Proline & Glycine & Lucien & Lysine \\
\hline $\mathbf{I}_{5} \times \mathbf{T}_{1}$ & $30.886 \mathrm{a}$ & $8.267 \mathrm{bcd}$ & $28.226 \mathrm{a}$ & $0.126 n$ & $0.246 \mathrm{ij}$ & $0.252 \mathrm{j}$ & $0.079 \mathrm{~m}$ \\
\hline $\mathbf{I}_{5} \times \mathbf{T}_{2}$ & $41.377 \mathrm{a}$ & $9.167 \mathrm{bc}$ & $22.812 \mathrm{~b}-\mathrm{f}$ & $0.186 \mathrm{n}$ & 0.365 hij & $0.373 \mathrm{j}$ & $0.188 \mathrm{~m}$ \\
\hline $\mathbf{I}_{\mathbf{5}} \times \mathbf{T}_{\mathbf{3}}$ & $50.598 \mathrm{a}$ & $9.167 \mathrm{bc}$ & $22.569 \mathrm{~b}-\mathrm{f}$ & $0.394 \mathrm{mn}$ & 0.614 hij & $0.526 \mathrm{ij}$ & $0.349 \mathrm{~lm}$ \\
\hline $\mathbf{I}_{5} \times \mathbf{T}_{4}$ & 38.109 a & 10.767 a & $19.088 \mathrm{fgh}$ & $0.159 \mathrm{n}$ & $0.282 \mathrm{ij}$ & $0.280 \mathrm{j}$ & $0.100 \mathrm{~m}$ \\
\hline $\mathbf{I}_{5} \times \mathbf{T}_{5}$ & 37.928 a & $6.067 \mathrm{~g}$ & $17.412 \mathrm{gh}$ & $2.298 \mathrm{ij}$ & $2.683 \mathrm{de}$ & $3.788 \mathrm{e}$ & $2.218 \mathrm{gh}$ \\
\hline$I_{5} \times T_{6}$ & 46.156 a & $9.200 \mathrm{~b}$ & $20.216 \mathrm{~d}-\mathrm{h}$ & $3.530 \mathrm{fg}$ & $2.990 \mathrm{de}$ & $4.926 \mathrm{~cd}$ & $3.578 \mathrm{f}$ \\
\hline $\mathbf{I}_{5} \times \mathbf{T}_{7}$ & 51.678 a & $8.233 \mathrm{bcd}$ & 20.172 d-h & $0.624 \mathrm{mn}$ & 0.854 ghi & 0.818 hij & $0.572 \mathrm{klm}$ \\
\hline $\mathbf{I}_{5} \times \mathbf{T}_{8}$ & $38.385 \mathrm{a}$ & $7.933 \mathrm{~b}-\mathrm{e}$ & $22.530 \mathrm{~b}-\mathrm{f}$ & 4.334 cde & $4.012 \mathrm{c}$ & $5.952 \mathrm{a}$ & $4.358 \mathrm{de}$ \\
\hline $\mathbf{I}_{\mathbf{5}} \times \mathbf{T}_{\mathbf{9}}$ & 35.996 a & $8.133 \mathrm{~b}-\mathrm{e}$ & $22.691 \mathrm{~b}-\mathrm{f}$ & $4.734 \mathrm{~cd}$ & $4.122 \mathrm{c}$ & $6.094 \mathrm{a}$ & $4.902 \mathrm{~cd}$ \\
\hline $\mathbf{I}_{\mathbf{5}} \times \mathbf{T}_{10}$ & $48.668 \mathrm{a}$ & $8.833 \mathrm{bc}$ & $22.547 \mathrm{~b}-\mathrm{f}$ & $1.772 \mathrm{jk}$ & $1.315 \mathrm{fg}$ & $1.276 \mathrm{gh}$ & $0.898 \mathrm{jkl}$ \\
\hline $\mathbf{I}_{5} \times \mathbf{T}_{11}$ & 48.619 a & $8.933 \mathrm{bc}$ & $23.130 \mathrm{~b}-\mathrm{f}$ & $1.869 \mathrm{ijk}$ & $1.683 \mathrm{f}$ & $1.663 \mathrm{~g}$ & $1.469 \mathrm{ij}$ \\
\hline $\mathbf{I}_{5} \times \mathbf{T}_{12}$ & $40.223 \mathrm{a}$ & $7.400 \mathrm{~d}-\mathrm{g}$ & $20.890 \mathrm{c}-\mathrm{g}$ & $3.274 \mathrm{fg}$ & $3.032 \mathrm{~d}$ & $2.954 \mathrm{f}$ & $2.658 \mathrm{~g}$ \\
\hline $\mathbf{I}_{5} \times \mathbf{T}_{13}$ & $48.900 \mathrm{a}$ & $8.133 \mathrm{~b}-\mathrm{e}$ & $20.481 \mathrm{~d}-\mathrm{h}$ & 3.886 ef & $3.682 \mathrm{c}$ & $5.624 \mathrm{ab}$ & 3.876 ef \\
\hline $\mathbf{I}_{10} \times \mathbf{T}_{1}$ & $28.470 \mathrm{a}$ & $6.167 \mathrm{~g}$ & $25.671 \mathrm{abc}$ & $0.296 \mathrm{n}$ & $0.198 \mathrm{j}$ & $0.326 \mathrm{j}$ & $0.134 \mathrm{~m}$ \\
\hline $\mathbf{I}_{10} \times \mathbf{T}_{2}$ & $38.241 \mathrm{a}$ & 6.800 efg & $23.536 \mathrm{a}-\mathrm{f}$ & $0.534 \mathrm{mn}$ & 0.376 hij & $0.582 \mathrm{ij}$ & $0.392 \mathrm{~lm}$ \\
\hline $\mathbf{I}_{10} \times \mathbf{T}_{3}$ & $32.309 \mathrm{a}$ & $7.833 \mathrm{c}-\mathrm{f}$ & $24.881 \mathrm{a}-\mathrm{d}$ & $0.698 \mathrm{lmn}$ & 0.442 hij & 0.672 hij & $0.422 \mathrm{klm}$ \\
\hline $\mathbf{I}_{10} \times \mathbf{T}_{4}$ & 28.739 a & $7.400 \mathrm{~d}-\mathrm{g}$ & 24.394 a-e & $0.412 \mathrm{mn}$ & 0.286 hij & $0.466 \mathrm{ij}$ & $0.252 \mathrm{~m}$ \\
\hline $\mathbf{I}_{10} \times \mathbf{T}_{5}$ & 31.669 a & $6.833 \mathrm{efg}$ & $25.830 \mathrm{ab}$ & $2.960 \mathrm{gh}$ & $3.952 \mathrm{c}$ & $3.730 \mathrm{e}$ & $3.492 \mathrm{f}$ \\
\hline $\mathbf{I}_{10} \times \mathbf{T}_{6}$ & $31.692 \mathrm{a}$ & $6.467 \mathrm{~g}$ & 24.296 a-e & $3.322 \mathrm{fg}$ & $4.212 \mathrm{c}$ & $3.824 \mathrm{e}$ & 3.726 ef \\
\hline $\mathbf{I}_{10} \times \mathbf{T}_{7}$ & $31.024 \mathrm{a}$ & $6.500 \mathrm{fg}$ & 20.686 d-h & $0.998 \mathrm{~lm}$ & $0.898 \mathrm{gh}$ & 1.114 ghi & $1.158 \mathrm{ijk}$ \\
\hline $\mathbf{I}_{10} \times \mathbf{T}_{8}$ & $30.742 \mathrm{a}$ & 6.800 efg & 19.559 e-h & $4.204 \mathrm{de}$ & $7.181 \mathrm{a}$ & $5.562 \mathrm{abc}$ & $6.558 \mathrm{~b}$ \\
\hline $\mathbf{I}_{10} \times \mathbf{T}_{9}$ & $28.288 \mathrm{a}$ & $7.000 \mathrm{~d}-\mathrm{g}$ & $22.585 \mathrm{~b}-\mathrm{f}$ & $6.912 \mathrm{a}$ & $6.774 \mathrm{a}$ & $5.948 \mathrm{a}$ & $7.290 \mathrm{a}$ \\
\hline $\mathbf{I}_{10} \times \mathbf{T}_{10}$ & $31.360 \mathrm{a}$ & $6.867 \mathrm{efg}$ & $21.066 \mathrm{~b}-\mathrm{g}$ & $1.334 \mathrm{kl}$ & $1.462 \mathrm{fg}$ & $1.608 \mathrm{~g}$ & 1.590 hi \\
\hline $\mathbf{I}_{10} \times \mathbf{T}_{11}$ & 35.594 a & $6.467 \mathrm{~g}$ & $20.678 \mathrm{~d}-\mathrm{h}$ & 2.498 hi & $2.412 \mathrm{e}$ & $2.920 \mathrm{f}$ & $2.218 \mathrm{gh}$ \\
\hline $\mathbf{I}_{10} \times \mathbf{T}_{12}$ & $31.955 \mathrm{a}$ & 7.900 b-e & $20.508 \mathrm{~d}-\mathrm{h}$ & $4.940 \mathrm{c}$ & $5.126 \mathrm{~b}$ & $4.730 \mathrm{~d}$ & $5.174 \mathrm{c}$ \\
\hline $\mathbf{I}_{10} \times \mathbf{T}_{13}$ & $28.518 \mathrm{a}$ & $7.367 \mathrm{~d}-\mathrm{g}$ & $15.964 \mathrm{~h}$ & $5.742 \mathrm{~b}$ & $5.526 \mathrm{~b}$ & $5.128 \mathrm{bcd}$ & $5.960 \mathrm{~b}$ \\
\hline L.S. $D_{(p \leq 0.05)}$ & n.s & 1.360 & 4.913 & 0.641 & 0.615 & 0.688 & 0.637 \\
\hline
\end{tabular}

Table 7. The effect of seasons on yield quantitative and qualitative characters

\begin{tabular}{c|c|c|c|c|c|c|c}
\hline Seasons & $\begin{array}{c}\text { Total yield } \\
\left(\mathbf{t ~ h a}^{-1}\right)\end{array}$ & $\begin{array}{c}\text { T.S.S } \\
(\boldsymbol{\%})\end{array}$ & $\begin{array}{c}\text { Starch } \\
(\boldsymbol{\%})\end{array}$ & Proline & Glycine & Lucien & Lysine \\
\hline First season 2017 & 36.311 a & $7.704 \mathrm{a}$ & $22.481 \mathrm{a}$ & $2.383 \mathrm{a}$ & $2.386 \mathrm{a}$ & $2.718 \mathrm{a}$ & $2.371 \mathrm{a}$ \\
Second season 2018 & $37.159 \mathrm{a}$ & $7.717 \mathrm{a}$ & $22.016 \mathrm{a}$ & $2.386 \mathrm{a}$ & $2.489 \mathrm{a}$ & $2.736 \mathrm{a}$ & $2.447 \mathrm{a}$ \\
\hline L.S.D.D $_{(\mathbf{p} \leq \mathbf{0 . 0 5})}$ & n.s & n.s & n.s & n.s & n.s & n.s & n.s \\
\hline
\end{tabular}


The treatment of mycorrhizae inoculation gave the highest values for water use efficiency; this may be due to its high ability to produce the glomalin compound, which binds the soil minutes to each other and to the aggregation of aggregates. as well as the mycelium hypha played a major role by increasing the soil mass and stability (Fokom et al., 2012) indicates that there are positive correlations of correlations between organic matter and chlorine associated with Glomalin Related Soil Protein (GRSP). Peng et al. (2013) recorded that the fertilized soil with mycorrhizae increases the stability of its aggregates as a result of the action of the mycorrhizae hypha and the result of its production of glomalin, a watery and insoluble molybdenum protein compound that contributes to the formation and increase stability of the soil complexes where it is released to them and reduce their hydration because it is a glue-absorbing composite. (Martin et al., 2012 and $\mathrm{Wu}$ et al., 2013) reported that organic matter also plays an important role in improving the properties of physical, chemical and biological soil. The Glycyrrhiza glabra extract contains various elements such as calcium, iron, silicon, aluminum, magnesium, sulfur, potassium, zinc, and phosphorus, which play an important role in growth (Vispute and Khopade, 2011). Licorice extract also contains mevalonic acid, which enters the synthesis of gibberellins (Moses et al., 2002). ALHamdani and AL-Zuhairy (2017) nitrogen enter the formation of chlorophyll as well as the formation of amino acids in the formation of Chloroplast, which increases the leaves content of chlorophyll. Myint et al. (2010) showed that chlorophyll was directly related to the plant content of nitrogen.

Potassium is also associated with many other important phylogenetic functions, including activation of enzymes, regulation of opening and closing of stents, as well as its important role in the synthesis of ATP, where the electrostatic charge in the ATP production sites is closely related to the $\mathrm{K}^{+}$(Prajapati and Modi, 2012) and sugars (Van Brunt and Sultenfnss, 1998), water and nutrient transport (Thomas and Thomas, 2009) and protein synthesis and starch (Patil, 2011).

The combination of the licorice extract and the inoculation of the mycorrhizae on the composition of amino acids, especially in the case of a lack of irrigation or dehydration, and the interference of the element nitrogen and potassium religions reduce the presence of amino acids in potato tubers.

\section{Conclusion and recommendation}

The 5 days irrigation interval had highly effect on the total yield, while 10 days irrigation period had a significant effect on the tuber hardness, and most of the amino acid content in the tubers. The treatments were significantly affected on all of the studied characters with the exception of starch\% in the tubers. The interaction of the 10 days irrigation interval with both of the Mycorrhizal inoculation and Spraying with $\left(2.5 \mathrm{~g} \mathrm{~L}^{-1}\right) \mathrm{KCl}+$ Spraying with $\left(6 \mathrm{~g} \mathrm{~L}^{-1}\right)$ Glycyrrhiza glabra extract recorded significant effects on total soluble solid percentage, tuber hardness and all of the amino acid in the tuber.

Carrying out more investigation on different irrigation intervals as well as more biotic and abiotic treatments to determine their effect on the quantitative and qualitative traits in in different locations and for different years in Sulaimani region to generalize the results and to ensure the potato yield stability. Reduce the use of chemical fertilizers and replace them by increasing the use of different plant extracts at different concentrations according to the recommendations of specialists in that field. The use of 
fungal, bacterial, bio inoculators, and transpiration compounds and potassium salts on potato is recommended to increase the resistance to abiotic stress.

\section{REFERENCES}

[1] Al-Alousi, S. A (2013): Effect of adding potassium to soil, spraying and spraying with organic extract in potato growth and yield. - Kufa Journal of Agricultural Sciences 5(1): 120-135.

[2] Alavijeh, M. K., Yaghmaei, S. (2016): Biochemical production of bioenergy from agricultural crops and residue in Iran. - Waste Management 52: 375-394.

[3] Al-Hamdani, S. A., Al-Zuhairy, H. T. H. (2017): Effect of organic, chemical fertilizers and plant density on 2-some growth and yield characteristics of cauliflower Brassica oleracea var. botrytis. - Diyala Agricultural Sciences Journal 9 (2): 104-114.

[4] Al-Rawi, K. M., and Khalaf-Allah, A. M. (1980): Design and analysis of agricultural experiments. - El Mousel Univ. Iraq 19: 487.

[5] A.O.A.C. (1970): Official Methods of Analysis. 11 th $^{\text {ed. }}$ - Association of Official Analytical Chemistry 101, Washington, DC.

[6] A.O.A.C. (1986): Association of Official Agricultural Chemists. Official and Tentative Methods of Analysis. 13th Ed. - Association of Official Agricultural Chemists, Washington, DC.

[7] Asmaa, R. M., Magda, M. H. (2010): Increasing productivity of potato plants (Solanum tuberosum L.) By using potassium fertilizer and humic acid application. - International Journal of Academic research (2): 83-88.

[8] Ati, A., Nafaou, S. M. (2012): Effect of potassium fertilization on growth, yield and water use efficiency of irrigated potato. - MISR Journal Agricultural Engineering 29(2): 735-744.

[9] Ati, A., Al-Sahaf, F., Wally, D., Thamer, T. (2013): Effects of potassium humate fertilizers and irrigation rate on potato yield and consumptive use under drip irrigation method. - Journal of Agricultural Science and Technology (3): 803-810.

[10] Basu, P. S., Sharma, A., Garg, I. D., Sukumaran, N. P. (1999): Tuber sink modifies the photosynthetic response in potato under water stress. - Environmental and Experimental Botany (42): 25-39.

[11] Birhane, E., Sterck, F. J., Fetene, M., Bongers, F., Kuyper, T. W. (2012): Arbuscular mycorrhizal fungi enhance photosynthesis, water use efficiency, and growth of frankincense seedlings under pulsed water availability conditions. - Oecologia 169(4): 895-904.

[12] Caverzan, A., Passaia, G., Rosa, S. B., Ribeiro, C. W., Lazzarotto, F., Margis-Pinheiro, M. (2012): Plant responses to stresses: the role of ascorbate peroxidase in antioxidant protection. - Genetics and Molecular Biology 35(4): 1011-1019.

[13] Central Statistical Organization (2016). Ministry of Planning, Republic of Iraq.

[14] Chakraborty, S., Chakraborty, N., Agrawal, L., Ghosh, S., Narula, K., Shekhar, S., Datta, A. (2010): Next-generation protein-rich potato expressing the seed protein gene AmA1 is a result of proteome rebalancing in the transgenic tuber. - Proceedings of the National Academy of Sciences 107(41): 17533-17538.

[15] Duc, N. H., Mayer, Z., Pék, Z., Helyes, L., Posta, K. (2017): Combined inoculation of arbuscular mycorrhizal fungi, Pseudomonas fluorescens, and Trichoderma spp. for enhancing defense enzymes and yield of three pepper cultivars. - Applied Ecology and Environmental Research 15(3): 1815-1829.

[16] El Sagan, M. A. M. (2015): Effect of some natural extracts on the growth and productivity of cucumber under sandy soil conditions. - Int. J. Adv. Res. 3(9): 677-686. 
[17] Esho, T., Enzlin, P., Van Wolputte, S., Temmerman, M. (2010): Female genital cutting and sexual functioning. In search of an alternate theoretical model. - African Identities 8(3): 221-234.

[18] Fageria, N. K. (2016): The Use of Nutrients in Crop Plants. - CRC Press, Boca Raton, FL.

[19] Fan, H., Aubry, S., Arsenlis, A., El-Awady, J. A. (2016): Grain size effects on dislocation and twinning mediated plasticity in magnesium. - Scripta Materialia 112: 50-53.

[20] FAOSTAT (2019). Food and Agricultural Organization of the United Nations, Rome.

[21] Finkel, T., Holbrook, N. J. (2000): Oxidants, oxidative stress and the biology of aging. Nature 408(6809): 239.

[22] Fokom, R., Adamou, S., Teugwa, M. C., Begoude Boyogueno, A. D.., Nana, W. L., Ngonkeu, M. E. L., Tchameni, N. S., Nwaga, D., Tsala Ndzomo, G., Amvam Zollo, P. H. (2012): Glomalin-related soil protein, carbon, nitrogen and soil aggregate stability as affected by land use variation in the humid forest zone of south Cameroon. - Soil Tillage Res 120: 69-75.

[23] Gander, P. W., Tanner, C. B. (1976): Leaf growth, tuber growth, and water potential in potatoes. - Crop Science 16: 534-538.

[24] Graser, T. A., Godel, H. G., Albers, S., Földi, P., Fürst, P. (1985): An ultra-rapid and sensitive high-performance liquid chromatographic method for the determination of tissue and plasma free amino acids. - Analytical Biochemistry 151(1): 142-152.

[25] Itakura, Y., Ichikawa, M., Mori, Y., Okino, R., Udayama, M., Morita, T. (2001): How to distinguish garlic from the other allium vegetables. - J. Nutr. 131: 955-962.

[26] Khalel, A. M. S., Hado, E. K. (2011): The effect of applying the extract of garlic, liquorice root and algaren on growth and yield of kidney bean (Phaseolus vulgaris L). 5th Scientific Conference of College of Agriculture, Tikrit University, 27-28 April.

[27] Khosravifar, S., Yarnia, M., Khorshidi Benam, M. B., Hosseinzadeh Moghbeli, A. H. (2008): Effect of potassium on drought tolerance in potato cv. Agria. - Journal of Food, Agriculture and Environment 6(3-4): 236-241.

[28] Lazim, Z. S., Sulaiman, S. M. (2012): Effect of gibberellic and liquorice extract on seed germination of black seed (Nigella sativa L.). - Iraq. J.Agric. Res. 17(1): 105113.

[29] Mafakheri, A., Siosemardeh, A., Bahramnejad, B., Struik, P., Sohrabi, Y. (2010): Effect of drought stress on yield, proline and chlorophyll contents in three chickpea cultivars. Australian Journal of Crop Science 4: 580-585.

[30] Martin, S. L., Mooney, S. J., Dickinson, M. J., West, H. M. (2012): Soil structural responses to alterations in soil microbiota induced by the dilution method and mycorrhizal fungal inoculation. - Pedobiologia 55(5): 271-281.

[31] Matar, M. H., Saad, A. M., Ahmad, F. R. (2012): Effect of the treatment by gibberellic acid liquorice extract on growth and yield of potato. - Journal of Diyala for Agriculture Science 4(1): 220-234.

[32] Moses, T. N., Abdul-Jabbar, W. A., Elwy, A. N. (2002): Study of some local licorice root powder components (Glycyrrhiza glabra L.). - Iraq. J. of Agric. Sci. 33(4): 30-38.

[33] Murchie, E. H., Pinto, M., Horton, P. (2009): Agriculture and the new challenges for photosynthesis research. - New Phytologist 181(3): 532-552.

[34] Muthoni, J., Kabira, J. N. (2016): Potato production under drought conditions: identification of adaptive traits. - International Journal of Horticulture 6.

[35] Myint, A., Yama Kawa T., Kajihara, Y., Zenmoy, T. (2010): Application of different organic and mineral fertilizers on the growth, yield and nutrient accumulation of rice in a Japanese ordinary paddy field. - Sci. Word. Journal 5(2): 47-54.

[36] Najmaddin, P. M., Whelan, M. J., Balzter, H. (2017): Estimating daily reference evapotranspiration in a semi-arid region using remote sensing data. - Remote Sensing 9(8): 779.

[37] Patil, S. V., Patil, C. D., Salunke, B. K., Salunkhe, R. B., Bathe, G. A., Patil, D. M. (2011): Studies on characterization of bioflocculant exopolysaccharide of Azotobacter 
indicus and its potential for wastewater treatment. - Applied Biochemistry and Biotechnology 163(4): 463-472.

[38] Peng, S., Guo, T., Liu, G. (2013): The effects of arbuscular mycorrhizal hyphal networks on soil aggregations of purple soil in southwest China. - Soil Biology and Biochemistry 57: 411-417.

[39] Prajapati, K. B., Modi, H. A. (2012): Isolation and characterization of potassium solubilizing bacteria from ceramic industry soil. - CIBTech Journal Microbiol 1(2-3): 814.

[40] Sabry, G. H., Rizk-Alla, M. S., Abd El-Wahab, M. A. (2009): Influence of effective micro-organisms, seaweed extract and amino acids application on growth, yield and bunch quality of Red globe grapevines. - J. Agric. Sci. Mansoura Univ. 34(6): 59015921.

[41] Saran, V. P., Chhabra, P. (2014): Studies on the parameters of potato processing. - Int. Interdisciplinary Research Journal 4: 320-33.

[42] Thomas, T. C., Thomas, A. C. (2009): The vital role of potassium in the osmotic mechanism of stomata aperture modulation and its link with potassium deficiency. Plant Signal Behaviour 4(3): 240-243.

[43] Van Brunt, J. M., Sultenfuss, J. H. (1998): Better crops with plant food. - Potassium: Functions of Potassium 82(3): 4-5.

[44] Vispute, S., Khopade, A. (2011): Glycyrrhiza glabra Linn.-“Klitaka”: a review. - Int. Journal Pharma Bio Sci. 2(3): 42-51.

[45] Wang, C., Deng, P., Chen, L., Wang, X., Ma, H., Hu, W., He, G. (2013): A wheat WRKY transcription factor TaWRKY10 confers tolerance to multiple abiotic stresses in transgenic tobacco. - PloS One 8(6): e65120.

[46] Wu, Q. S., Xia, R. X., Zou, Y. N. (2006): Reactive oxygen metabolism in mycorrhizal and non-mycorrhizal citrus (Poncirus trifoliata) seedlings subjected to water stress. Journal of Plant Physiology 163(11): 1101-1110.

[47] Zelelew, D. Z., Lal, S., Kidane, T. T., Ghebreslassie, B. M. (2016): Effect of potassium levels on growth and productivity of potato varieties. - American Journal of Plant Sciences 7(12): 1629.

[48] Zotarelli, L., Scholberg, J. M., Dukes, M. D., Muñoz-Carpena, R., Icerman, J. (2009): Tomato yield, biomass accumulation, root distribution, and irrigation water use efficiency on sandy soil, as affected by nitrogen rate and irrigation scheduling. - Agricultural Water Management 96(1): 23-34. 